EFFECT OF URBAN RUNOFF ON THE QUALITY OF LAKES

IN EAGAN, MINNESOTA

By Lan H. Tornes

U.S. GEOLOGICAL SURVEY

Water-Resources Investigations Report 86-4331

Prepared in cooperation with the

CITY OF EAGAN, MINNESOTA

St. Paul, Minnesota

1989 


\section{UNITED STATES DEPARTMENT OF THE INTERIOR}

DONALD PAUL HODEL, Secretary

GEOLOGICAL SURVEY

Dallas L. Peck, Director

For additional information

write to:

District Chief

U.S. Geological Survey

Water Resources Division

702 Post Office Building

St. Paul, Minneosta 55101
Copies of this report can be purchased from

U.S. Geological Survey Books and Open-File Reports Section Federal Center

Building Al

Denver, Colorado 80225 


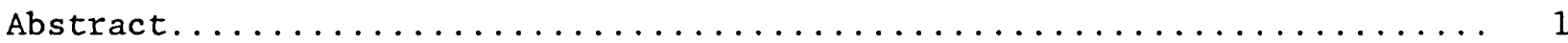

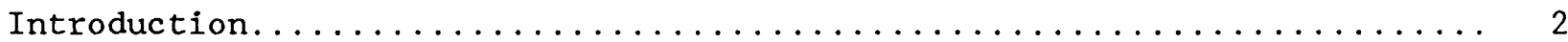

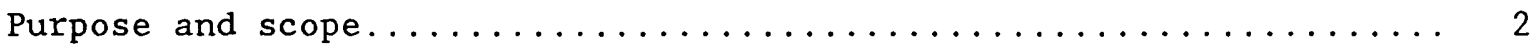

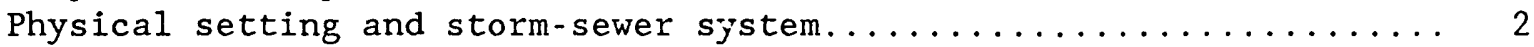

Methods and approach.............................. 4

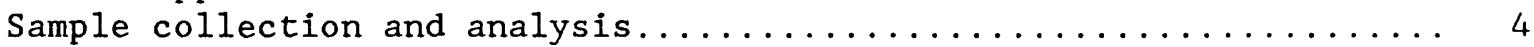

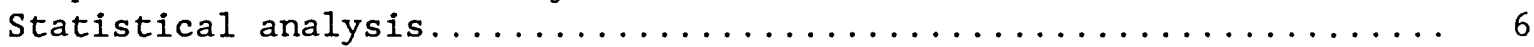

Modeling................................. 7

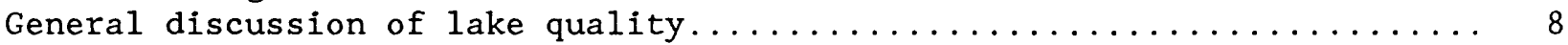

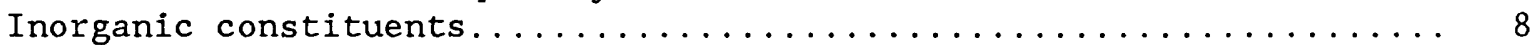

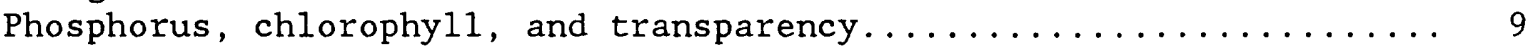

Trophic states................................ 11

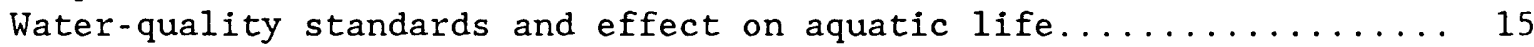

Quality of individual lakes............................ 16

Blackhawk Lake.............................. 20

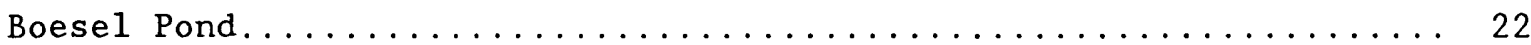

Burview Park Pond................................. 24

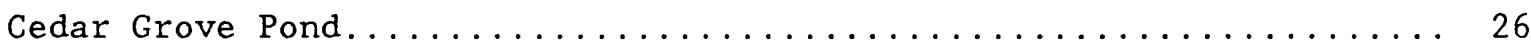

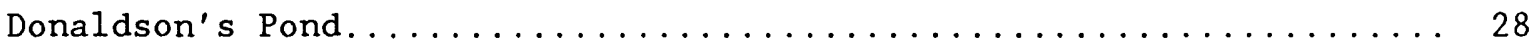

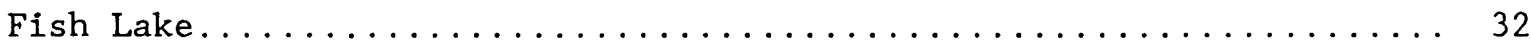

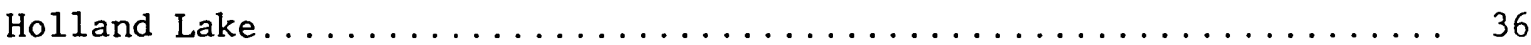

Jensen Lake.................................... 40

Lakeside Estates Lake............................. 42

Langhoven Pond............................... 44

Lemay Lake.................................. 46

McCarthy Lake............................... 48

Shanahan Pond................................. 50

Slater's Acres Pond.............................. 52

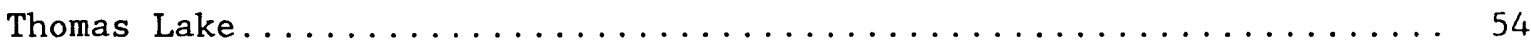

Wilderness Lake............................. 56

Evaluation of lake-quality models....................... 58

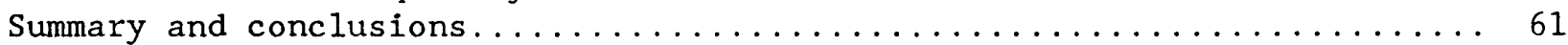

References cited................................. 63 


\section{ILLUSTRATIONS}

Page

Figure 1. Map showing location of lakes and ponds studied in Eagan,

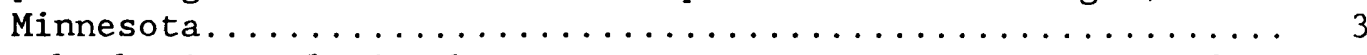

2. Graph showing relation between mean summer concentrations of total phosphorus and chlorophyll a in lakes............ 10

3. Graph showing relation between Secchi-disk transparency and chlorophyl1 a concentration.................. 12

\section{TABLES}

Table 1. Numbers and types of laboratory determinations made on samples

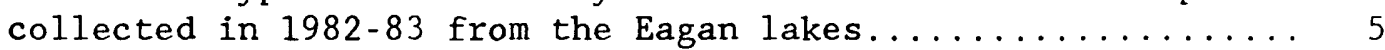

2. Trophic-state indices for the Eagan lakes................ 14

3. Results of phosphorus-prediction models................ 59

4. Results of phosphorus-prediction models compared to the median

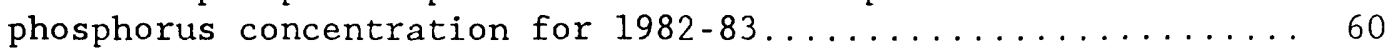

\section{CONVERSION FACTORS AND ABBREVIATIONS}

For use of readers who prefer to use metric (International system) units, conversion factors for terms used in this report are listed below:

\section{Multiply inch-pound unit}

$\operatorname{acre}(\mathrm{ac})$

acre-foot (acre-ft)

foot $(f t)$

inch (in)
By

0.4047

1234

0.3048

2.540
To obtain metric unit

hectare (ha) cubic meter $\left(\mathrm{m}^{3}\right)$

meter ( $m$ )

centimeter $(\mathrm{cm})$

For readers who want to convert temperature in degrees Celcius $\left({ }^{\circ} \mathrm{C}\right)$ to degrees Fahrenheit $\left({ }^{\circ} \mathrm{F}\right)$, the following formula may be used:

$$
1.8^{\circ} \mathrm{C}+32={ }^{\circ} \mathrm{F}
$$




\title{
EFFECT OF URBAN RUNOFF ON THE QUALITY OF LAKES
}

\author{
IN EAGAN, MINNESOTA
}

By L. H. Tornes

\begin{abstract}
Sixteen lakes in the city of Eagan, Minnesota, were sampled during 1982-83 to detect water-quality changes that might have occurred because of urbanization since a previous study conducted during 1972-78. Each of the lakes was sampled five times to determine $\mathrm{pH}$, specific conductance, dissolved oxygen, water temperature, transparency, and concentration of dissolved chloride. Three determinations of chlorophyll were made for each of the lakes near the end of the study, and additional determinations were made for a few lakes of particular interest.
\end{abstract}

Most of the lakes have been incorporated into the city's storm-runoff system for use as retention basins during large storms. The chemistry of the lakes appears to be degraded by urban runoff. Chloride concentrations were significantly higher in six lakes than during the previous study, and remained elevated (about $30 \mathrm{milligrams}$ per liter) in four other lakes. The association between increased chloride and specific conductance with runoff from urban areas suggests that the lakes are subject to contamination by chloride commonly present in urban runoff, and chloride concentrations harmful to aquatic life may have been associated with high specific conductance measured in one of the lakes.

Analysis of the data collected for this study indicate that the chemistry of the lakes changes, adjusting to a variety of influences including (1) alternate loading and flushing by runoff, (2) excessive average-annual precipitation, (3) changing ground-water and lake interactions, and (4) changing land use in the lake watersheds. Some lakes affected by urban runoff had reduced concentrations of total phosphorus; however, other lakes unaffected by urban runoff also had significantly lower phosphorus, suggesting that increased precipitation may have diluted the lake water. Ten phosphorusloading models tested or developed during the previous study generally were found to be inadequate for describing the results of this study. The trophic status of 12 lakes improved but declined in the other 41 akes, and productivity increased 38 percent in what had been the least-eutrophic lake. 


\section{INTRODUCTION}

The city of Eagan, with a 1980 population of 20,700 (U.S. Department of Commerce, 1982), is a rapidly growing suburb of the Twin Cities Metropolitan Area in southeastern Minnesota. The evolution of this area from an agricultural community to one dominated by light industry and extensive residential development has led to concerns about the effects of urbanization on the quality of the numerous lakes and ponds in the city. Seventeen lakes and ponds were sampled during 1972-78 to establish the baseline quality of the Eagan lakes. Findings from the first 2 years of this study were presented in a report by Have (1975). Ayers and others (1980) presented the lake-quality data determined from 6 years of sampling, explained changes in lake quality observed during the study, and evaluated several phosphorus-loading models that might be used to determine changes in lake quality that result from urbanization. Sixteen of the 17 lakes were resampled in 1982-83.

During the last several years, many of the lakes and ponds in Eagan have been incorporated into the storm-sewer system to serve as retention basins for storm-water runoff according to the plans of Bonestroo and others (1978). Concern over the effect of storm water and continued urbanization on the quality of the Eagan Lakes resulted in a follow-up study performed by the U.S. Geological Survey in cooperation with the city of Eagan. Although most of the work had been completed, installation of the storm-sewer system continued during this study.

\section{Purpose and Scope}

The purposes of this report are to summarize the results of the 1982-83 study and to compare the results with those obtained during the previous study to detect changes in lake quality. Trends in lake-water quality are evaluated to determine their relation to land-use changes in the watersheds. Lakequality models developed during the previous study (Ayers and others, 1980) are retested using the expanded data base and updated values for the parameters in the models.

\section{Physical Setting and Storm-Sewer System}

The city of Eagan (fig. 1) is located in the northwestern part of Dakota County, Minnesota, and borders on the Minnesota River to the northwest. The mean annual precipitation for this area is about 27.5 inches, most of which occurs during April through September. The lakes included in this study are situated in clay, sand, and gravel deposited by glaciers about 10,000 years ago. None of the lakes have natural outlets at normal stages, indicating that lake stages depend on precipitation and interactions with the local ground water; normal lake elevations probably reflect the changes in precipitation and the elevation of the water table in the immediate vicinity of the lakes. The lakes, ponds, and marshes in this region probably are major points of recharge to the ground-water system following heavy rains and snowmelt. Regional ground-water flow is towards the Minnesota River. 


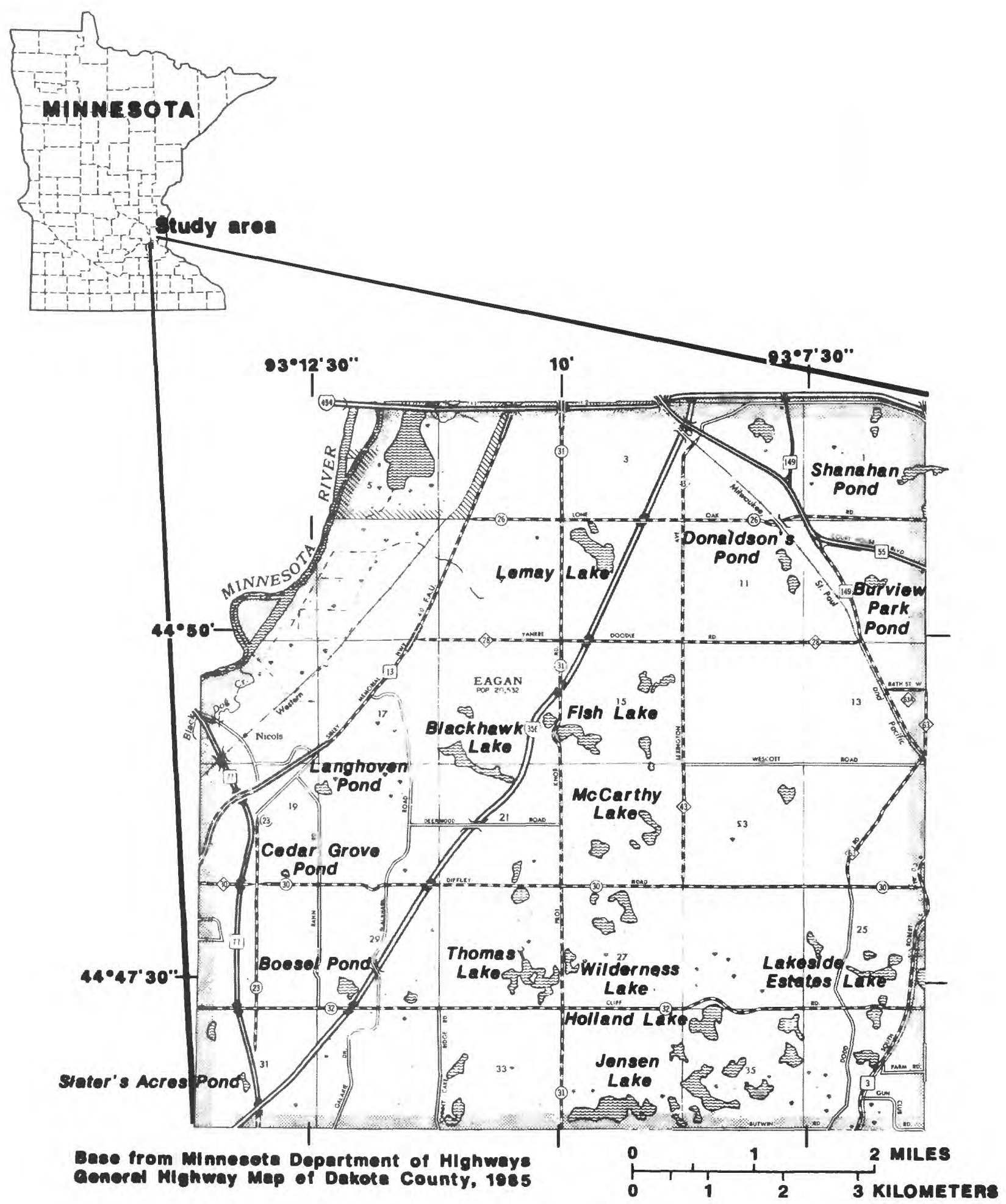

Figure 1.--Location of lakes and ponds studied in Eagan, Minnesota 
Many of the lakes studied are included in the city's storm-sewer system. This system, described in Bonestroo and others (1984), provides for the conveyance of storm and snowmelt water away from residential and industrial areas into and through lakes, ponds, and hollows. The system is designed to retain part of the runoff in each basin before the additional water continues to the subsequent basin. Water levels of some of the lakes and ponding areas are expected to remain elevated for extended periods during the open-water season, until the lakes reach equilibrium with the ground-water system.

\section{METHODS AND APPROACH}

\section{Sample Collection and Analysis}

Sixteen of the original 17 lakes and ponds that were sampled in the 1970's were resampled in July and August 1982 and in February, Apri1, and August 1983. Samples were collected and field measurements made at or near the deepest part of each lake in areas as free of rooted aquatic vegetation as possible.

During each visit, measurements were made to determine the Secchi-disk transparency during ice-free conditions and the depth at the sampling site. Measurements of water temperature, specific conductance, $\mathrm{pH}$, and dissolved oxygen usually were made at three or more points in the sampling vertical using multiparameter meters that were calibrated and checked at the beginning and end of each day of sampling. Occasionally, however, one-parameter meters were used to measure $\mathrm{pH}$ and specific conductance, and Winkler titrations were done to measure dissolved oxygen (Skougstad and others, 1979).

Water samples were collected from about 1 foot below the surface of each lake and within a few feet of the bottom of Holland and Fish Lakes. The samples were filtered and (or) preserved before shipment to the U.S. Geological Survey laboratory in Doraville, Georgia. Chlorophyll concentrations were determined by the methods described in Greeson and others (1979a and 1979b). The methods used to determine the concentration of all other constituents are described in Skougstad and others (1979).

Table 1 shows the number and type of determinations made on the samples collected from each of the Eagan lakes. The quality of the water in Blackhawk, Fish, Holland, and Thomas Lakes was of particular concern to the community because of their recreational value; therefore, these lakes were more intensively sampled than the others. Samples from these lakes were analyzed for total and volatile suspended solids, dissolved nitrite plus nitrate, total ammonia plus organic nitrogen, and dissolved phosphorus, in addition to analyses for dissolved chloride, chlorophy11, and total phosphorus that were done on samples from all the lakes. Samples for most constituents, except chlorophyl1, also were collected near the bottom of Fish and Holland Lakes. 
Table 1.--Numbers and types of laboratory determinations made on samples collected in 1982-83 from the Eagan lakes

\begin{tabular}{|c|c|c|c|c|c|c|c|c|c|}
\hline \multirow[b]{3}{*}{ Lake } & \multirow{3}{*}{$\begin{array}{l}\text { Dissolved } \\
\text { chloride }\end{array}$} & \multirow{2}{*}{\multicolumn{2}{|c|}{ Chlorophyll }} & \multicolumn{4}{|c|}{ Nitrogen } & \multirow{2}{*}{\multicolumn{2}{|c|}{ Suspended solids }} \\
\hline & & & & \multicolumn{2}{|c|}{ Phosphorus } & \multirow{2}{*}{$\begin{array}{c}\text { Dissolved } \\
\text { nitrite + } \\
\text { nitrate }\end{array}$} & \multirow{2}{*}{$\begin{array}{c}\text { Total } \\
\text { ammonia + } \\
\text { organic }\end{array}$} & & \\
\hline & & $\underline{\mathbf{a}}$ & $\underline{\mathrm{b}}$ & Total & Dissolved & & & Total & Volatile \\
\hline Blackhawk & 5 & 5 & 5 & 5 & 5 & 5 & 5 & 5 & 5 \\
\hline Boesel & 3 & 3 & 3 & 3 & - & - & - & - & - \\
\hline Burview Park & 4 & 3 & 3 & 4 & 1 & 1 & 1 & 1 & 1 \\
\hline Cedar Grove & 3 & 3 & 3 & 3 & - & - & - & - & - \\
\hline Donaldson's & 3 & 3 & 3 & 3 & - & - & - & - & - \\
\hline Fish, top & 5 & 5 & 5 & 5 & 4 & 5 & 4 & 4 & 4 \\
\hline Fish, bottom & 5 & - & - & 5 & 5 & 5 & 5 & 5 & 5 \\
\hline Holland, top & 5 & 5 & 5 & 5 & 5 & 5 & 5 & 5 & 5 \\
\hline Holland, bottom & 5 & - & - & 5 & 5 & 5 & 5 & 5 & 5 \\
\hline Jensen & 3 & 3 & 3 & 3 & - & - & - & - & - \\
\hline Lakeside Estates & 3 & 3 & 3 & 3 & - & - & - & - & - \\
\hline Langhoven & 2 & 2 & 2 & 2 & - & - & - & - & - \\
\hline Lemay & 3 & 3 & 3 & 3 & - & - & - & - & - \\
\hline McCarthy & 3 & 3 & 3 & 3 & - & - & - & - & - \\
\hline Shanahan & 3 & 3 & 3 & 3 & - & - & - & - & - \\
\hline Slater's Acres & 3 & 3 & 3 & 3 & - & - & - & - & - \\
\hline Thomas & 5 & 5 & 5 & 5 & 5 & 5 & 5 & 5 & 5 \\
\hline Wilderness & 3 & 3 & 3 & 3 & - & - & - & - & - \\
\hline
\end{tabular}


Because the remaining 12 lakes in table 1 were less important in terms of water use, samples for analysis of dissolved chloride, chlorophyll, and total phosphorus were not collected until the last three visits to the lakes. Burview Park Pond was sampled for other purposes in July 1982; concentrations of dissolved chloride, total phosphorus, total and volatile suspended solids, total ammonia plus organic nitrogen, dissolved nitrite plus nitrate nitrogen, pathogenic-indicator bacteria, and genera of phytoplankton were determined because local residents were concerned about health hazards to persons that swim in the lake. A sample was not collected from Langhoven Pond in February 1983, because the lake was frozen to the bottom.

The data interpreted in this report has been published in the annual water-data reports of the U.S. Geological Survey $(1975-79,1983-84)$ or is available in the Minnesota District office of the U.S. Geological Survey.

Lake and drainage areas and normal and maximum lake elevations were obtained from a report by Bonestroo and others (1984), that contains the most recent and readily accessible information about the lakes and watersheds in the study area. Developed areas within the lake watersheds were planimetered from illustrations contained in the appendices of that report.

\section{Statistical Analysis}

The concentrations obtained for samples collected during the previous study were compared to sample concentrations determined for this study. The Wilcoxon two-sample statistical test (Snedecor and Cochran, 1967) was performed to determine whether values of chloride, phosphorus, specific conductance, transparency and other selected measurements for this study were significantly different from values for the previous study but the usefulness of this test was limited because only 5 or fewer values from this study were available for testing. Values were considered to be significantly different if the Wilcoxon test showed that they had at least a 95 percent chance of being different other than from chance alone.

Certain water-quality values obtained during this study required special treatment when they were analyzed statistically because they were limited by analytical sensitivity (detection limits) or physical constraints (shallow lake depth). Readings of Secchi-disk transparency that were limited by the relatively shallow lake bottom would have been greater, but are summarized as if the values were correct and are qualified by footnotes when listed in tables. Concentrations of nitrite plus nitrate nitrogen and dissolved phosphorus frequently were below detection limits and were reported as $<0.1$ or $<0.01 \mathrm{mg} / \mathrm{L}$ (milligrams per liter), respectively. In statistical summaries these and other "less than" values are treated as real numbers except in the computation of the arithmetic mean, when the less-than values are assumed to equal one-half the detection limit. 


\section{Modeling}

Ten equations were tested or developed by Ayers and others (1980) to simulate the loading of phosphorus into the lakes and possibly to predict their future quality. Many of the parameter values, including drainage area, lake depth, runoff coefficients, and phosphorus-loading rates, used in these models have changed substantially since that report was published, particularly following the installation of the storm-sewer system. The models were retested for this report using updated parameter values to determine their applicability to the study lakes.

The drainage areas used in the phosphorus-loading models are those listed in subsequent tables as "direct drainage area." Most of the lakes studied have total drainage areas that are many times larger than the direct drainage area as a result of the installation of the storm-drainage system. The increased drainage area probably will increase the volume of water received by each of the lakes, but because this is difficult to quantify, being dependent on storm intensity, ponding-area capacity, and many other factors, it will not be used in the models.

A greater load of phosphorus probably will be received by the Eagan lakes because of the increased drainage area, but this also would be difficult to quantify. However, much of the phosphorus in runoff, being sorbed to sediment particles, will settle to the bottom in ponding areas adjacent to and upstream from the lakes receiving runoff. To keep the phosphorus models simple, it is assumed that the only phosphorus received by the lakes will come from direct drainage and the phosphorus from indirect runoff will be negligible; however, if sediments become anoxic or large storms disturb sediments in ponding areas, phosphorus could be mobilized and carried to the lakes.

For Holland and Fish Lakes, differences in lake elevations and corresponding lake areas from 1978 to 1984 reported by Bonestroo and others (1978 and 1984), were used to calculate the change from 1972-78 average depths reported by Ayers and others (1980) to 1982-83 average depths. The shallowest lakes, Langhoven, McCarthy, and Slater's Acres, were assumed to have mean depths equal to the mean maximum depth over the study period because of their virtually flat bottoms. Jensen Lake was assumed to have a mean depth equal to 90 percent of mean maximum depth, whereas the mean depth for the rest of the lakes was assumed to equal 80 percent of the mean maximum depth (Ayers and others, 1980).

Several coefficients used for input to the phosphorus-loading models discussed later in this report were obtained from the results of a Twin Cities-area urban-runoff study (Ayers and others, 1985). Mean annual surface runoff coefficients were 0.14 for undeveloped areas and 0.27 for developed areas. Phosphorus concentrations in urban (storm sewered) runoff, rural runoff, and precipitation used to calculate a value for LOADP, discussed later in this report, were assumed to be $0.780,0.310$, and $0.038 \mathrm{mg} / \mathrm{L}$, respectively. 
The average annual precipitation during this study was determined from the mean monthly averages for the Minneapolis-St. Paul Airport and the Rosemount Agricultural Experiment Station (National Oceanic and Atmospheric Administration, 1983-84). An annual average of 38.88 inches of precipitation during the study was about 11 inches above normal. Because this above-normal value might misrepresent a process that averages the effects of many years of climatic influence, the mean annual precipitation for the area, 27.5 inches, was used in the phosphorus-loading models.

Additional information concerning the derivation of input parameters and the development of the phosphorus-loading models is discussed in Ayers and others (1980).

\section{GENERAL DISCUSSION OF LAKE QUALITY}

\section{Inorganic Constituents}

Median specific conductance was higher in this study than previously for 11 of the 16 lakes sampled, although it was lower in 4 lakes. Increased specific conductance indicates that the concentration of salts dissolved in the Eagan lakes has increased substantially since the previous study. The specific conductance measured near the surface ranged from $68 \mu \mathrm{S} / \mathrm{cm}$ (microsiemens per centimeter at $\left.25^{\circ} \mathrm{C}\right)^{1}$ in Shanahan Pond to $695 \mu \mathrm{S} / \mathrm{cm}$ in Burview Park Pond. Median specific conductance ranged from 102 to $462 \mu \mathrm{S} / \mathrm{cm}$, also in Shanahan and Burview Ponds, respectively. The median specific conductance for McCarthy Lake, $275 \mu \mathrm{S} / \mathrm{cm}$, was the second highest median in the lakes studied.

It is possible that the high specific conductance in Burview Park Pond is related to incorporation of this pond into the city's storm-water drainage system. The median specific conductance in Burview Park Pond during the first study was $239 \mu \mathrm{S} / \mathrm{cm}$, which was about half that measured during this study.

Generally, every lake that had increased specific conductance also had increased concentrations of dissolved chloride. The correlation coefficient between chloride and conductance exceeded 0.70 in nine of the lakes. Median chloride concentrations for this study were at least double what they previously had been in five of the lakes sampled, with a three-fold increase found in Burview Park Pond and a six-fold increase in Blackhawk Lake.

Median chloride concentrations were lower in two of the lakes studied. The chloride concentration in Jensen Lake was only 4 percent lower than during the previous study--a drop from 7.2 to $6.9 \mathrm{mg} / \mathrm{L}$. However, the 55-percent reduction measured at Cedar Grove Pond was substantial, and probably resulted from flushing out water that had a high median chloride concentration ( $38 \mathrm{mg} / \mathrm{L}$ ) since the previous study.

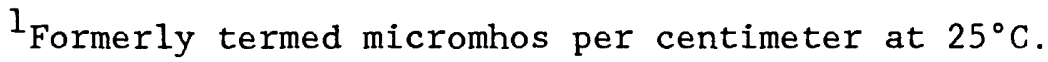


More detailed water-chemistry data were collected during the previous study than for this study. See Ayers and others (1980) for a discussion of these data.

\section{Phosphorus, Chlorophyll, and Transparency}

Ayers and others (1980) determined in the previous study that phosphorus probably was the nutrient limiting phytoplankton growth in the Eagan lakes, with the possible exception of Boesel, Cedar Grove, Donaldson's, Langhoven, McCarthy, and Slater's Acres lakes and ponds. Based on this assumption and because of limited funding, total phosphorus was the only plant nutrient measured during this study in all but a few lakes.

Median surficial concentrations of total phosphorus during this study ranged from $0.02 \mathrm{mg} / \mathrm{L}$ in Fish Lake to $0.18 \mathrm{mg} / \mathrm{L}$ in Langhoven Lake. Median concentrations were $0.05 \mathrm{mg} / \mathrm{L}$, or less, in nine lakes sampled. Median phosphorus concentrations were greater than $0.10 \mathrm{mg} / \mathrm{L}$ in Cedar Grove Pond and Thomas and Langhoven Lakes.

Median surficial phosphorus concentrations declined at least 50 percent from those found during the previous study in five of the lakes. The average phosphorus concentration for all the lakes combined was 39 percent lower in this study. Only Holland Lake had higher phosphorus concentrations--near the surface and near the bottom.

The reasons for the decreased surficial phosphorus can not be readily determined from the available data, although many explanations are possible, including (1) increased precipitation of phosphorus from the lake water to the lake sediments, (2) reduced loading of phosphorus in runoff to the lakes, (3) more efficient flushing of the lakes following the installation of storm sewers, and (or) (4) dilution by the above-normal precipitation during the study period. A 2-year drought occurred during the previous study (Ayers and others, 1980), whereas, during this study, average annual precipitation was about 11 inches above normal. It seems that flushing and dilution could have been the primary causes of reduced total-phosphorus concentrations.

Average concentrations of chlorophyll a in the lakes increased substantially since the previous study. Chlorophyll a concentrations were more than double those found in the previous study for 10 of the lakes, and were 11 times as great in Langhoven Lake. Increased concentrations of chlorophyll a indicate that, although phosphorus concentrations have declined in the Eagan lakes, productivity has increased.

Generally, it is uncommon for chlorophyll concentrations to increase while phosphorus concentrations decrease because both are closely related to algal productivity (Reckhow, 1979). Figure 2 shows the relation between summer (MaySeptember) concentrations of total phosphorus and chlorophyll a in the Eagan lakes during each of the studies, along with regression relations determined by other investigators. These investigators (Carlson, 1977, and Dillon and Rigler, 1974) used data from a large number of lakes and determined the line that best described the relation between total phosphorus and chlorophyll a in 


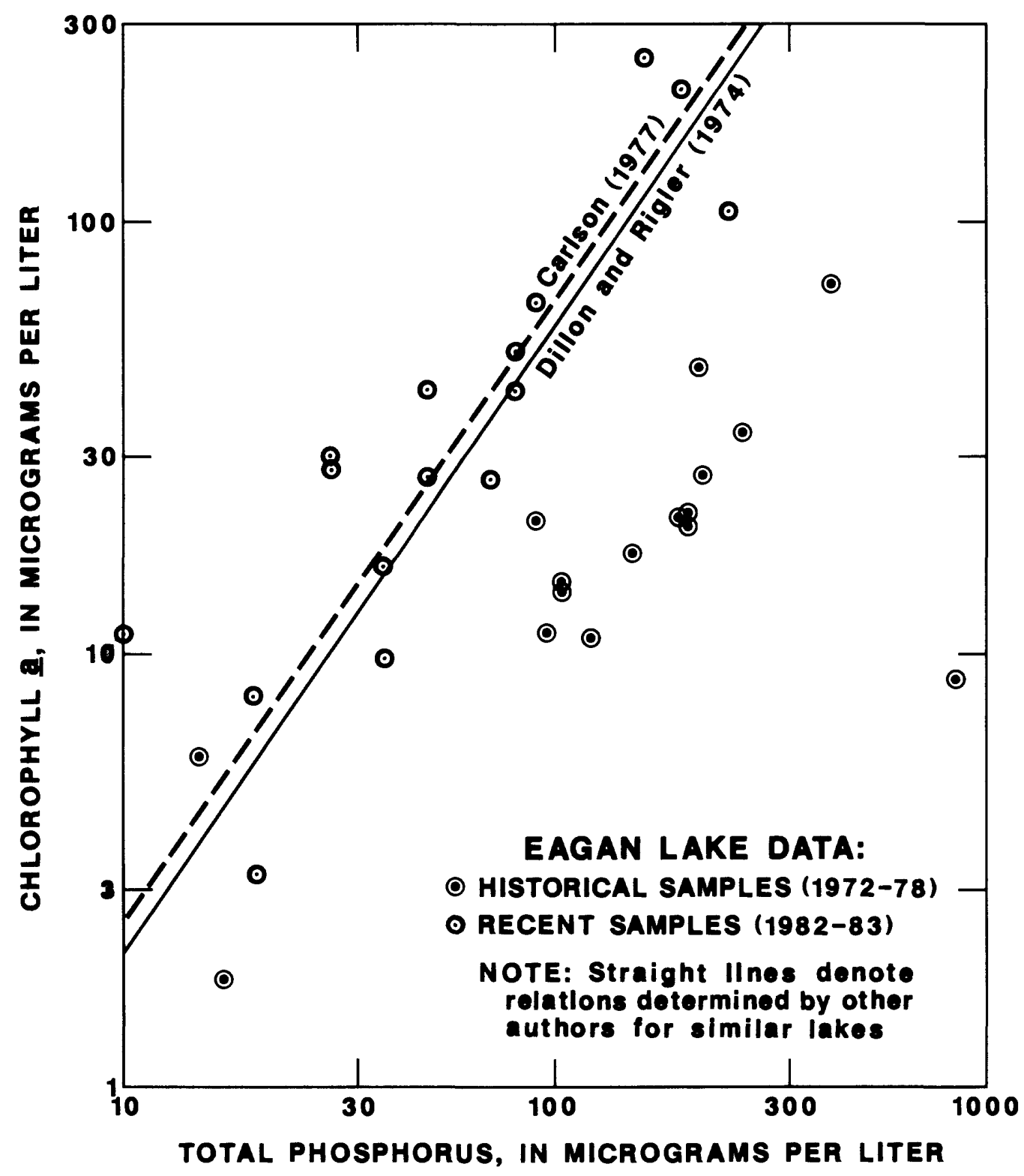

Figure 2.--Relation between mean summer concentrations of total phosphorus and chlorophyll a in lakes 
these lakes; most of which were similar, in character, to the Eagan lakes. The 1972-78 data tend to plot below and to the right of the regression lines shown on the figure whereas the 1982-83 data more closely follow the relations expressed by the regression lines. This difference indicates that more phosphorus was available to phytoplankton than was being used or that the amount of chlorophyll a detected in the 1972-78 samples was abnormally low.

Secchi-disk transparency and chlorophyll a also are closely related measurements based on algal productivity (Reckhow, 1979). Figure 3 displays this relation for 1972-78 and 1982-83 summer data collected from the Eagan lakes with two regression lines developed by investigators (Carlson 1977, and Jones and Bachmann, 1974) using data methods similar to those used to determine the relation between total phosphorus and chlorophyll a. It is apparent that the 1972-78 data tend to plot below and to the left of the regression lines, whereas the 1982-83 data plot more closely to the regression lines, particularly the line developed by Carlson (1977). Although Secchidisk readings are subject to minor variations, the 1972-78 data deviates from the regression lines more than might ordinarily be expected. Figures 2 and 3 indicate that the chlorophyll a concentrations determined during analysis of the 1972-78 samples may have been much less than the amount actually in the water when sampled, which, considered with the instability of chlorophylls (Greeson and others, 1979a and 1979b,) suggests that much of the chlorophyll a sampled during the previous study had degraded before analysis and the results are not representative of lake concentrations.

The average transparency of the Eagan lakes, overall, has not changed since the previous study; however, substantial changes were observed in many individual lakes. Mean transparencies were higher in six of the lakes studied and a two-fold increase was observed in four of those lakes. Transparency declined in five of the lakes; the greatest reduction was found in Blackhawk Lake where the mean transparency decreased 0.6 meter.

The increased transparency in many of the lakes may result more from a change in depth than from improved clarity. Readings in several lakes were limited by shallow depth to lake bottom. Many of these lakes had greater average depths in this study than during the previous study, which could and likely did result in greater transparency than had previously been measured. This will be discussed in greater detail later in the report.

\section{Trophic States}

A useful tool for comparative lake-quality studies, called the trophicstate index (TSI), was developed by Carlson (1977). The TSI is computed from any of three relatively inexpensive measurements made during the summer months and gives a relative indication of phytoplankton productivity in most lakes. A low TSI indicates a "cleaner," more oligotrophic lake, whereas a high TSI indicates a more productive, eutrophic lake. The three measurments used for the TSI, total phosphorus concentration, chlorophyll a concentration, and Secchi-disk transparency, relate to productivity as follows: When phosphorus is the nutrient limiting phytoplankton growth, as often occurs, nearly all the available phosphorus in water near the lake surface will be used for energy 


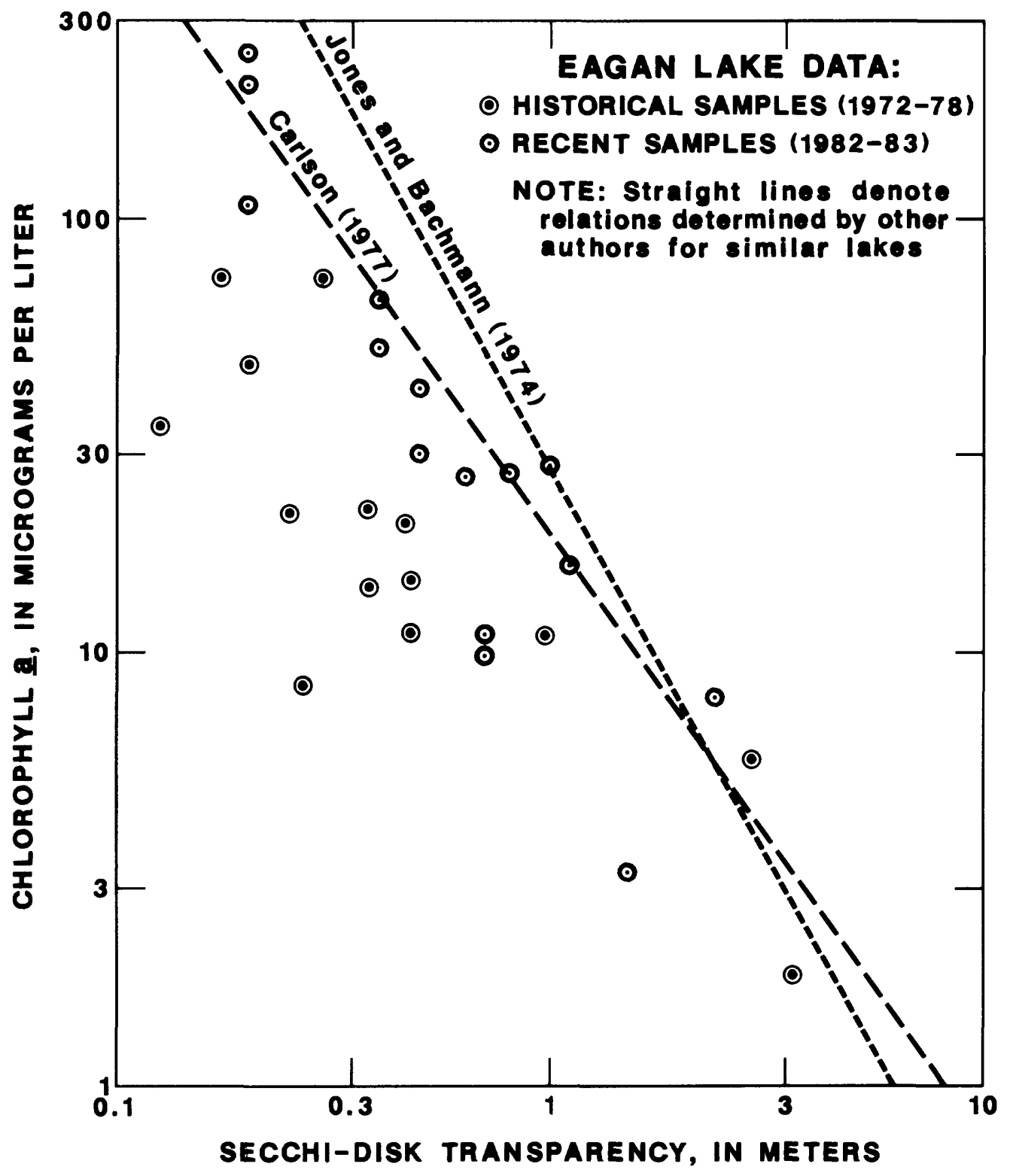

Figure 3.--Relation between Secchi-disk transparency and chlorophyll a concentration 
storage and transfer in the cells of living, active phytoplankton, therefore, the phosphorus concentration can be a good indicator of phytoplankton productivity; chlorophyll $a$ is the primary photosynthetic pigment for phytoplankton and degrades rapidly when the cells die, making it a good indicator of phytoplankton productivity; Secchi-disk transparency is a measurement of light attenuation dependent on the amount of turbidity and color in the water, but in relatively un-colored, non-turbulent lakes, it provides a measurement of light attenuation caused by phytoplankton cells: denser phytoplankton populations in more productive lakes will result in reduced transparency.

The equations used to compute the TSI are as follows:

$$
\begin{aligned}
& \operatorname{TSI}_{(\mathrm{SD})}=10\left(6-\frac{\ln (\mathrm{SD})}{\ln (2)}\right) \\
& \operatorname{TSI}_{(\mathrm{chla})}=10\left(6-\frac{2.04-[0.68 \ln (\mathrm{chla})]}{\ln (2)}\right) \\
& \operatorname{TSI}_{(\mathrm{TP})}=10\left(6-\frac{\ln \left[\frac{65}{\mathrm{TP}}\right]}{\ln (2)}\right)
\end{aligned}
$$

Where $1 \mathrm{n}=$ natural logarithm

$\mathrm{SD}=$ Secchi-disk transparency in meters

chla $=$ chlorophyll a concentration in micrograms per liter, and

$\mathrm{TP}=$ total phosphorus concentration in micrograms per liter.

Table 2 is a comparative listing of the mean TSI's for the Eagan lakes determined from data collected during this study and the previous study (Ayers and others, 1980). The values are computed only from the summer values of total phosphorus, Secchi-disk transparency, and chlorophyll a, as recommended by Carlson (1977).

Many of the TSI values for each lake are not useful for comparisons. Many transparency measurements were limited by the depth of the lake and, although they indicate that the TSI has improved, are greater only because of increased lake depth. It was determined that measured 1972-78 chlorophyl1 a concentrations were much less than expected and would not be appropriate measurements with which to detect changes in the TSI. Total phosphorus concentrations appear to be the most reliable measurement of TSI for this and the previous stady and are the measurement that will be discussed here. 
Table 2.--Trophic-state indices for the Eagan lakes

[ Means one or more of the Secchi-disk measurements was limited by the depth to the bottom of the lake or pond. The actual trophic-state index value for transparency is less than the one shown in the table.]

\begin{tabular}{|c|c|c|c|c|c|c|}
\hline \multirow[t]{2}{*}{ Lake } & \multicolumn{2}{|c|}{$\begin{array}{c}\text { Total } \\
\text { phosphorus }\end{array}$} & \multicolumn{2}{|c|}{ Transparency } & \multicolumn{2}{|c|}{ Chlorophyl1 a } \\
\hline & $1972-78$ & $1982-83$ & $1972-78$ & $1982-83$ & $1972-78$ & $1982-83$ \\
\hline Blackhawk......... & 66 & 60 & $53 *$ & 67 & 48 & 62 \\
\hline 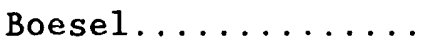 & 80 & 53 & 84 & 77 & 64 & 53 \\
\hline Burview........... & 67 & 58 & 69 & 60 & 54 & 62 \\
\hline Cedar Grove........ & 75 & 73 & 83 & 83 & 60 & 85 \\
\hline Donaldson........... & 58 & 49 & 68 & 64 & 51 & 63 \\
\hline 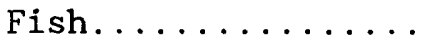 & 41 & 44 & 43 & 48 & 38 & 50 \\
\hline 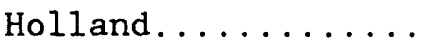 & 37 & 51 & 45 & 52 & 47 & 56 \\
\hline Jensen........... & 64 & 49 & 74 & $69 x$ & 55 & 64 \\
\hline Lakeside.......... & 71 & 63 & 75 & 77 & 56 & 69 \\
\hline Langhoven. . . . . . . . & 78 & 79 & $65 *$ & $83 *$ & 48 & 77 \\
\hline Lemay . . . . . . . . . . & 66 & 63 & 73 & 74 & 55 & 67 \\
\hline McCarthy.......... & 66 & 33 & $72 *$ & $57 *$ & 54 & 54 \\
\hline Shanahan.......... & 65 & 56 & $64 *$ & 69 & 60 & 67 \\
\hline Slater's Acres..... & 75 & 43 & $70 x$ & $57 *$ & 57 & 42 \\
\hline Thomas........... & 70 & 74 & 76 & 79 & 65 & 81 \\
\hline Wilderness........ & 70 & 65 & 79 & 69 & 65 & 72 \\
\hline
\end{tabular}


The average total phosphorus TSI for all the Eagan lakes declined more than 8 units since the previous study, and substantial changes occurred in many of the lakes. The TSI for eight lakes declined more than 10 percent and was more than 40 percent lower in Slater's Acres and McCarthy Lakes. The 38percent increase at Holland Lake was the only major rise in productivity observed in the lakes studied, and was accompanied by a substantial decrease in the transparency.

Based on the limited data used to prepare table 2, many of the lakes have changed their relative ranking based on TSI. Holland Lake had been the least productive lake, but became more productive than five other lakes. Blackhawk and Thomas, lakes that receive storm drainage from a large part of Eagan, are ranked much lower than they were earlier. Other lakes, such as McCarthy and Slater's Acres, showed notable improvement in their relative trophic states.

\section{Water-Quality Standards and Effect on Aquatic Life}

Criteria for drinking water and the protection of fisheries and recreation established by the Minnesota Pollution Control Agency were exceeded during some measurements made in the Eagan lakes for this study. Dissolved oxygen and $\mathrm{pH}$ were measurements that occasionally did not meet established criteria.

The $\mathrm{pH}$ of Class $\mathrm{A}$ fisheries and recreation should not exceed the range of 6.5 to 8.5 and Classes $B$ and $C$ should not exceed 6.5 to 9.0 (Minnesota Pollution Control Agency, 1978). The surficial pH of all the Eagan lakes sampled for this study occasionally exceeded 8.5 and in many lakes exceeded 9.0; some measured values were greater than $\mathrm{pH} 10.0$. The Class $\mathrm{A}, \mathrm{B}$, and C criteria were exceeded near the surface of the Eagan lakes during the summer because of high phytoplankton productivity. During photosynthesis, phytoplankton use most of the available carbon dioxide, causing the $\mathrm{pH}$ near the surface to become highly alkaline while a nearly neutral pH is maintained at depth.

Class A criteria for fisheries and recreation limit the dissolved oxygen concentration to a minimum of $7 \mathrm{mg} / \mathrm{L}$; Class B and C criteria establish a minimum of $5 \mathrm{mg} / \mathrm{L}$ (Minnesota Pollution Control Agency, 1978). Measurements of dissolved oxygen near the lake surface for this study were below the Class $\mathrm{A}$ criteria at least one time in every lake except Boesel Pond. Class B and C criteria were exceeded in all but four lakes. During the previous study, however, dissolved oxygen in each of those lakes was measured at concentrations below the Class $B$ and $C$ criteria. Minimum dissolved oxygen usually was measured in winter when consumption of oxygen during respiration and decomposition may exceed production from photosynthesis.

Measurements of dissolved chloride for this study did not exceed the Minnesota Pollution Control Agency (1978) criteria of $50 \mathrm{mg} / \mathrm{L}$ for Class A fisheries and recreation or the Class A domestic-consumption criterion of 250 $\mathrm{mg} / \mathrm{L}$. During the previous study, however, dissolved chloride during drought conditions did exceed $50 \mathrm{mg} / \mathrm{L}$ in several lakes. This suggests that the criteria could be exceeded again, possibly in many more lakes. High specific conductance near the bottom of Donaldson's Pond, discussed later in this report, suggests that the chloride concentration near the bottom of the lake 
exceeded the criterion for Class A domestic consumption established by the Minnesota Pollution Control Agency.

Using the lakes for retention of runoff from urban areas makes them susceptable to contamination with the variety of materials and chemicals that have become part of daily living. Lead from automobile and small-engine exhaust could be washed into the lakes and accumulate in the ecosystem. 0il and grease could be accidentally or intentionally drained into lakes and damage the ecosystems or detract from the esthetic quality of the lakes. Inadequately controlled organic chemicals, including carelessly applied pesticides and PCB's leaked from transformers and capacitors, also could adversely affect lake ecosystems.

\section{QUALITY OF INDIVIDUAL LAKES}

Following is a brief discussion of the quality of each of the lakes studied in Eagan. Accompanying the discussion are tables describing morphometric and water-quality characteristics of the lakes. The information below should help the reader understand the values displayed in the tables.

\section{MORPHOMETRY}

Direct drainage area - land directly adjacent to the lake that provides runoff directly to the lake without passing through ponding areas.

Lake area

Developed area
- the normal surface area of the lake.

- that part of the direct drainage area having substantial amounts of pavement and residential or commercial buildings .

Ponded drainage area - land that provides indirect runoff to the lake because water passes through ponding areas. This runoff generally is conveyed by the storm-water drainage system.

$1972-78$

average depth - see discussion of modeling in Methods and Approach section.

$1982-83$

average depth - see discussion of modeling in Methods and Approach section.

Normal elevation - the expected elevation of the lake surface above mean sea level based on long-term observations. 
Maximum elevation

Maximum measured depth

$\mathrm{N}$

$\operatorname{Max}$

Min

Mean

Med

Temperature

Specific

conductance

Dissolved oxygen

$\mathrm{pH}$

Dissolved chloride
- the lake-surface elevation at which the lake water would flow through natural or man-made outlets.

- the maximum depth measured during sample collection, $1972-78$ and $1982-83$.

\section{WATER QUALITY}

\section{Table Headings}

- number of measurements made

- maximum measured value

- minimum measured value

- an average value determined by summing all the values and dividing by $\mathrm{N}$

- median, a value such that half of the values are greater and half are less

\section{Constituents and Measurements}

$-{ }^{\circ} \mathrm{C}$ (degrees Celsius)

- $\mu \mathrm{S} / \mathrm{cm}$ at $25^{\circ} \mathrm{C}$ (microsiemens per centimeter at 25 degrees Celsius)

- mg/L (milligrams per liter)

- standard units

- mg/L as C1 (Chlorine)

Dissolved means that the chemical analysis for the constituent was made on the material in the water sample which passed through a $0.45-\mu \mathrm{m}$ (micrometer) membrane filter. (page 4, Skougstad and others, 1979). 
Nitrogen

$\mathrm{NO}_{2}+\mathrm{NO}_{3}$

$\mathrm{NH}_{4}+$ organic

Suspended solids

Volatile suspended solids

Transparency
Total means that the chemical analysis for the constituent was made on the total amount of the constituent in a representative water-suspended sediment sample, regardless of the constituent's physical or chemical form. This term is used only when the analytical procedure assures measurement of at least 95 percent of the constituent present in both the dissolved and suspended phases of the sample. (page 4, Skougstad and others, 1979).

- $\mathrm{mg} / \mathrm{L}$ as N (Nitrogen)

- nitrite plus nitrate nitrogen

- ammonia plus organic nitrogen

- $\mathrm{mg} / \mathrm{L}$

Suspended solids are the material retained on a glassfiber filter after a representative water sample has been passed through the filter and the filter has been heated at $105^{\circ} \mathrm{C}$. (page 573, Skougstad and others, 1979).

- $\mathrm{mg} / \mathrm{L}$

This is the difference between the weight of suspended solids and the weight of the residue after the suspended solids have been ignited at $550{ }^{\circ} \mathrm{C}$. (page 559, Skougstad and others, 1979).

- the approximate depth in meters at which a white "Secchi" disk, 20 centimeters in diameter, disappears from view in the water. 
This page is intentionally blank 
Blackhawk Lake

\section{INCREASED CHLORIDE CONCENTRATIONS MAY RESULT FROM ENLARGED WATERSHED}

Runoff from added urban drainage area may have caused a statistically significant increase in the concentration of dissolved chloride.

Dissolved chloride concentrations increased sixfold between the 1972-78 sampling and the 1982-83 sampling of the lake. Wetzel (1975) indicates that pollutional sources of chloride can greatly modify natural concentrations. It is likely that road salt has drained into Blackhawk Lake. Average concentrations of most other constituents measured, including dissolved and total phosphorus, total ammonia plus organic nitrogen, and suspended solids, were much lower than previously measured, and, with the exception of suspended solids, the differences had at least a 71-percent probability of being significant.

Transparency was much lower during the 1982-83 measurements of Blackhawk Lake. Total phosphorus concentrations had declined over this same period indicating that productivity decreased, so it is possible that some material introduced with runoff is interfering with the clarity, but was not measurable as suspended solids. Other explanations are that phytoplankton were making more efficient use of phosphorus than during the $1972-78$ sampling or that phosphorus is not a limiting nutrient and does not relate to productivity or transparency.

\section{WATER QUALITY}

[Samples taken near the surface of the lake.

See page 17 for descriptions of the constituents measured. -- , no data; <, less than]

\begin{tabular}{|c|c|c|c|c|c|c|c|c|c|c|c|}
\hline \multirow[b]{2}{*}{ Constituent } & \multirow{2}{*}{$\begin{array}{l}\text { Foot- } \\
\text { note }\end{array}$} & \multicolumn{5}{|c|}{$1972-78$} & \multicolumn{5}{|c|}{$1982-83$} \\
\hline & & $\mathrm{N}$ & Max & Min & Mean & Med & N & Max & Min & Mean & Med \\
\hline Temperature $\left({ }^{\circ} \mathrm{C}\right)$ & & 17 & 28.5 & 0.0 & 16.3 & 17.5 & 5 & 26.6 & 1.5 & 17.6 & 23.5 \\
\hline \multicolumn{12}{|l|}{ Specific conductance } \\
\hline$\left(\mu \mathrm{S} / \mathrm{cm}\right.$ at $\left.25^{\circ} \mathrm{C}\right)$ & & 17 & 300 & 103 & 217 & 225 & 4 & 290 & 195 & 234 & 224 \\
\hline Dissolved oxygen (mg/L) & & 17 & 16.5 & 0.2 & 9.4 & 10.1 & 5 & 14.1 & 0.6 & 7.2 & 7.6 \\
\hline $\mathrm{pH}$ (standard units) & & 17 & 10.2 & 7.4 & 8.0 & 8.5 & 5 & 9.2 & 6.7 & 7.3 & 9.0 \\
\hline Dissolved chloride ( $\mathrm{mg} / \mathrm{L}$ as $\mathrm{C} 1$ ) & 1 & 17 & 6.9 & 1.9 & 3.1 & 2.7 & 5 & 21.0 & 16.0 & 17.6 & 17.0 \\
\hline Total phosphorus (mg/L as P) & & 15 & .24 & $<.01$ & .11 & .08 & 5 & .10 & .05 & .07 & .06 \\
\hline Dissolved phosphorus ( $\mathrm{mg} / \mathrm{L}$ as $\mathrm{P}$ ) & & 6 & .07 & $<.01$ & .04 & .04 & 5 & .03 & $<.01$ & .02 & .02 \\
\hline \multicolumn{12}{|l|}{ Nitrogen (mg/L as $N)$} \\
\hline $\mathrm{NH}_{4}+$ Organic & & 10 & 8.5 & $\begin{array}{l}.1 \\
1.2\end{array}$ & 3.2 & 2.4 & $\begin{array}{l}5 \\
5\end{array}$ & 2.0 & $\begin{array}{l}.1 \\
.8\end{array}$ & 1.5 & 1.6 \\
\hline Suspended solids (mg/L) & & 8 & 41 & 0 & 20 & 20 & 5 & 10 & 2 & 7.2 & 8 \\
\hline Volatile suspended solids (mg/L) & & 0 & -- & -- & -- & -- & 5 & 10 & 1 & 3.8 & 2 \\
\hline Transparency (m) & 2 & 9 & 2.2 & .33 & 1.3 & 1.4 & 4 & .91 & .40 & .72 & .78 \\
\hline
\end{tabular}

1 The difference in the median values were found to be statistically significant as described on page 6 .

2 One or more measurements for the 1972-78 period were limited by the depth to the lake bottom. The maximum, mean, and median values may be great than those listed. 


\section{Eagan I.D.:BP-1 USGS I.D.:444912093110000}

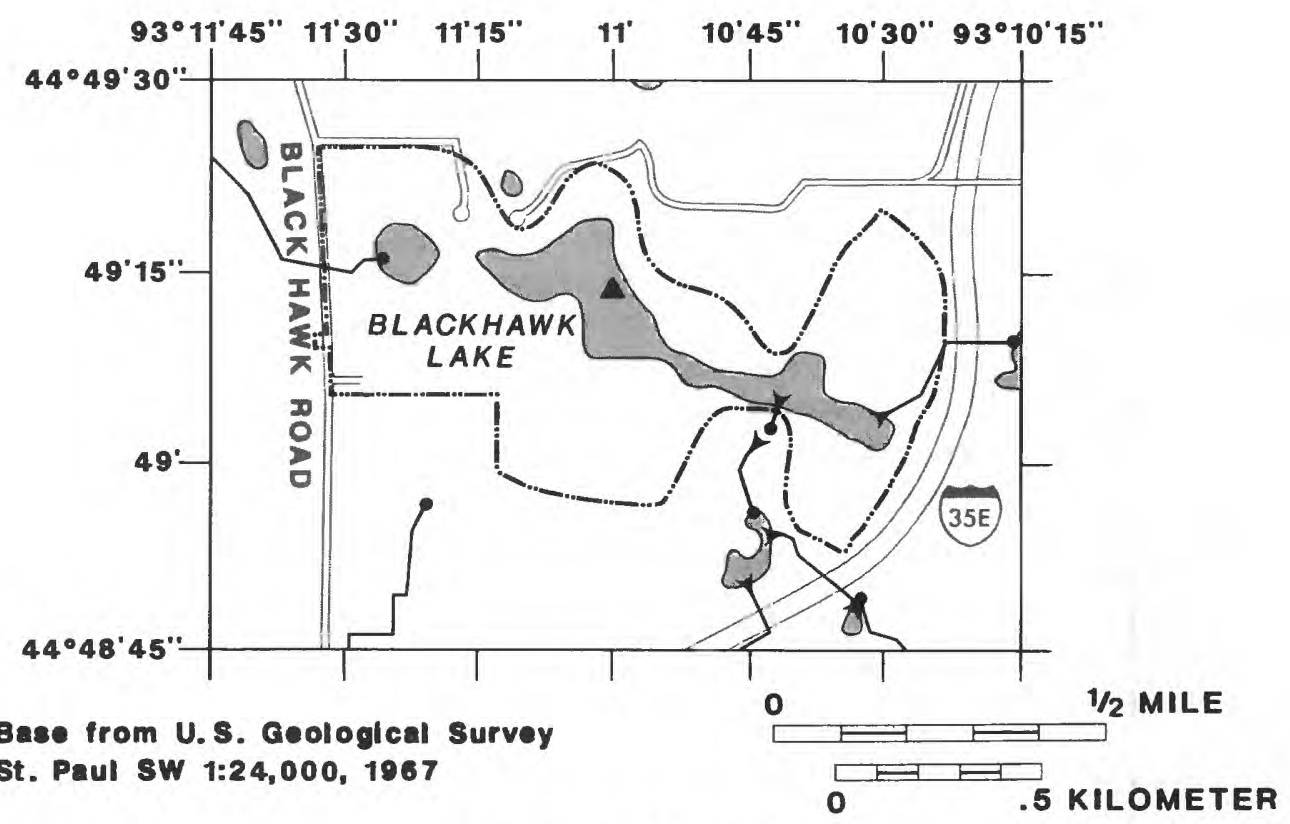

EXPLANATION

DIRECT DRAINAGE AREA

a SAMPLING SITE

— STORM-SEWER INLET TO LAKE

- STORM-SEWER OUTLET FROM LAKE

MORPHOMETRY

[See page 17 for a description of the lake and basin characteristics]

$\begin{array}{lrllr}\text { Direct Drainage Area (ac): } & 261 & \text { Average Depth, 1972-78 (ft): } & 4.3 \\ \text { Lake Area (ac): } & 41 & \text { Average Depth, 1982-83 (ft): } & 6.3 \\ \text { Developed Area (ac): } & 54 & \text { Normal Elevation (ft): } & 790.3 \\ \text { Ponded Drainage Area (ac): } & 9,573 & \text { Maximum Elevation (ft): } & 801.0\end{array}$

Maximum Measured Depth (ft): 10.5 


\section{Boese1 Pond}

\section{ADDED DRAINAGE AREA APPEARS NOT TO RESULT IN DEGRADATION OF BOESEL POND}

\section{A 1,400-percent increase in drainage area between the 1982-83 and 1972-78 samplings has not substantially increased specific conductance or chloride concentration.}

The data below indicate that constituents related to urban runoff, chloride and dissolved solids, have not degraded the quality of water in Boesel Pond. Average concentrations of phosphorus were much lower than measured during the 1972-78 study, and the statistical test gives a 90-percent probability that this difference is not the result of chance. However, increased median transparency, expected as a result of decreased total phosphorus concentrations, was not observed in Boese1 Pond. Four samples collected from the lake surface during 1972-74 were analyzed for dissolved and total phosphorus; the dissolved form represented from 12 to 85 percent of the total phosphorus. Dissolved phosphorus, which was available but not taken up by algae during the 1972-78 study, may have been incorporated into algal cells during the 1982-83 sampling allowing the maintenance of high productivity while total phosphorus concentrations were less.

The concentration of dissolved chloride and specific conductance of Boesel Pond may increase as a result of runoff from urban developments in the watershed. Substantial urban development has occurred or is planned in stormsewered subdivisions tributary to Boesel Pond. Interstate Highway I-35E was completed adjacent to the lake after field data were collected for this study. These areas could be a source of road salts that would affect the lake quality.

WATER QUALITY

[Samples taken near the surface of the lake.

See page 17 for descriptions of the constituents measured.]

\begin{tabular}{|c|c|c|c|c|c|c|c|c|c|c|c|}
\hline \multirow[b]{2}{*}{ Constituent } & \multirow{2}{*}{$\begin{array}{l}\text { Foot- } \\
\text { note }\end{array}$} & \multicolumn{5}{|c|}{$1972-78$} & \multicolumn{5}{|c|}{$1982-83$} \\
\hline & & $\mathrm{N}$ & $\operatorname{Max}$ & Min & Mean & Med & N & $\operatorname{Max}$ & Min & Mean & Med \\
\hline Temperature $\left({ }^{\circ} \mathrm{C}\right)$ & & 15 & 27.0 & 2.0 & 15.6 & 15.0 & 5 & 29.5 & 1.5 & 17.9 & 22.5 \\
\hline \multicolumn{12}{|l|}{ Specific conductance } \\
\hline$\left(\mu \mathrm{s} / \mathrm{cm}\right.$ at $\left.25^{\circ} \mathrm{C}\right)$ & & 15 & 170 & 92 & 123 & 122 & 4 & 165 & 91 & 128 & 128 \\
\hline Dissolved oxygen (mg/L) & & 15 & 16.8 & 0.7 & 9.8 & 9.6 & 5 & 14.1 & 7.4 & 10.7 & 10.9 \\
\hline pH (standard units) & & 15 & 10.5 & 6.9 & 7.6 & 8.7 & 3 & 8.9 & 7.2 & 7.6 & 7.7 \\
\hline Dissolved chloride (mg/L as C1) & & 15 & 7.3 & 3.7 & 5.4 & 5.1 & 3 & 9.1 & 5.6 & 6.9 & 6.0 \\
\hline Total phosphorus (mg/L as P) & & 13 & .53 & .07 & .24 & .19 & 3 & .20 & .04 & .10 & .05 \\
\hline Transparency (m) & 2 & 8 & 2.0 & .10 & .52 & .42 & 4 & .67 & .09 & .39 & .40 \\
\hline
\end{tabular}

2 One or more measurements for the 1972-78 period were limited by the depth to the pond bottom. The maximum, mean, and median values may be greater than those listed. 
BOESEL POND

Eagan I.D.:AP-11 USGS I.D.:444733093120900

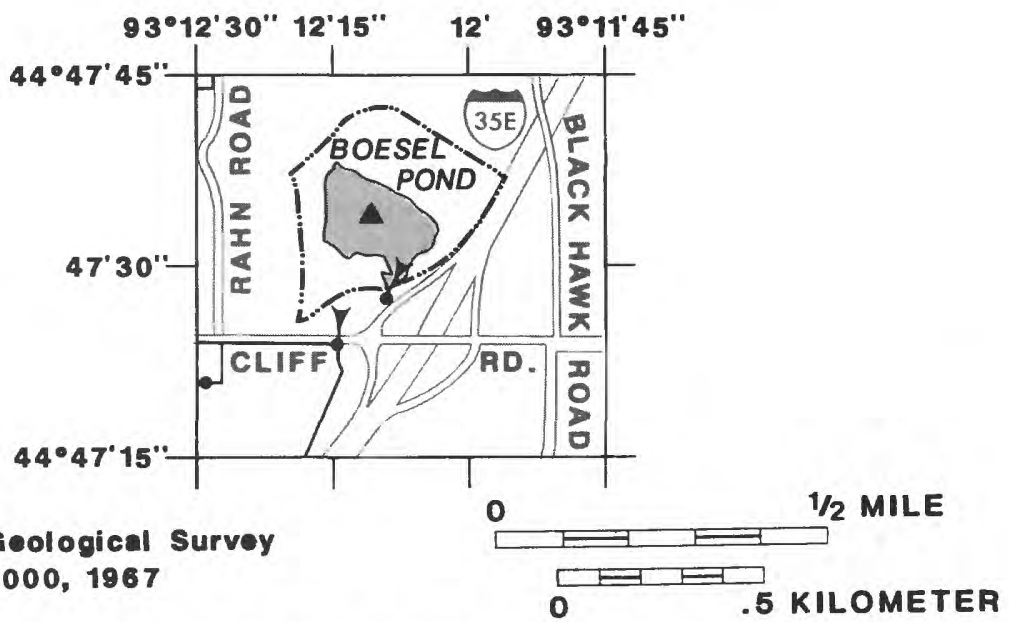

EXPLANATION

DIRECT DRAINAGE AREA

- SAMPLING Site

STORM-SEWER INLET TO LAKE

- STORM-SEWER OUTLET FROM LAKE

MORPHOMETRY

[See page 17 for a description of the lake and basin characteristics]

$\begin{array}{lrrrr}\text { Direct Drainage Area (ac): } & 43 & \text { Average Depth, 1972-78 (ft): } & 5.0 \\ \text { Lake Area (ac): } & 12 & \text { Average Depth, 1982-83 (ft): } & 5.8 \\ \text { Developed Area (ac): } & 1 & \text { Normal Elevation (ft): } & 889.2 \\ \text { Ponded Drainage Area (ac): } & 605 \quad \text { Maximum Elevation (ft): } & 893.0 \\ & & & \\ & & & \end{array}$




\title{
SIGNIFICANT INCREASE IN SPECIFIC CONDUCTANCE,
}

\author{
CHLORIDE, AND TRANSPARENCY OBSERVED
}

\section{Constituents of urban runoff added to Burview Park Pond may be inhibiting phytoplankton productivity.}

Data below show that statistically significant increases in chloride concentrations and specific conductance occurred in Burview Park Pond between the two sampling periods. Median transparency, which increased from 0.5 to 1.0 meter, also was significantly higher. Average total-phosphorus concentrations, however, remained virtually unchanged.

The decreased productivity, which is indicated by increased transparency without a substantial change in total-phosphorus concentrations, suggests that phytoplankton productivity is being inhibited or the phytoplankton are unable to use the available phosphorus. Many natural causes could explain reduced phytoplankton productivity including (1) increased grazing by zooplankton, (2) increased competition or inhibition from rooted aquatic macrophytes, or (3) an essential nutrient other than phosphorus has become limiting.

The coincidence between increased urban runoff, evidenced by elevated chloride concentrations, increased specific conductance, and decreased productivity, suggest that herbicides or other chemicals may have been introduced to the lake with the runoff and inhibited phytoplankton productivity. Have and others (1981) identified elevated concentrations of chrominum, copper, nickel, zinc, and arsenic in runoff to Alimagnet lake in Apple Valley, Minnesota, all of which are toxic to plants when present in sufficiently high concentrations (Gough and others, 1979). Added drainage areas include substantial parts of State Highways 49 and 55 that could be a source of chemicals and herbicides that could inhibit phytoplankton growth.

\section{WATER QUALITY}

[Samples taken near the surface of the lake.

See page 17 for descriptions of the constituents measured.]

\begin{tabular}{|c|c|c|c|c|c|c|c|c|c|c|c|}
\hline \multirow[b]{2}{*}{ Constituent } & \multirow{2}{*}{$\begin{array}{l}\text { Foot- } \\
\text { note }\end{array}$} & \multicolumn{5}{|c|}{$1972-78$} & \multicolumn{5}{|c|}{$1982-83$} \\
\hline & & $\mathbf{N}$ & $\operatorname{Max}$ & Min & Mean & Med & $\mathrm{N}$ & $\operatorname{Max}$ & Min & Mean & Med \\
\hline Temperature $\left({ }^{\circ} \mathrm{C}\right)$ & & 15 & 26.0 & 0.0 & 15.7 & 18.0 & 5 & 27.5 & 2.0 & 17.0 & 23.0 \\
\hline \multicolumn{12}{|l|}{ Specific conductance } \\
\hline$\left(\mu \mathrm{S} / \mathrm{cm}\right.$ at $\left.25^{\circ} \mathrm{C}\right)$ & 1 & 15 & 275 & 183 & 236 & 239 & 4 & 695 & 334 & 488 & 462 \\
\hline Dissolved oxygen (mg/L) & & 15 & 12.2 & 5.8 & 9.2 & 9.1 & 5 & 13.4 & 1.5 & 8.5 & 9.7 \\
\hline pH (standard units) & & 15 & 9.9 & 7.4 & 8.0 & 8.1 & 5 & 9.0 & 6.8 & 7.1 & 7.2 \\
\hline Dissoslved chloride (mg/L as $\mathrm{Cl}$ ) & 1 & 15 & 20.0 & 5.5 & 10.9 & 10.0 & 4 & 36.0 & 31.0 & 33.5 & 33.5 \\
\hline Total phosphorus (mg/L as $\mathrm{P}$ ) & & 13 & .14 & .02 & .10 & .10 & 4 & .55 & .04 & .18 & .06 \\
\hline Transparency $(\mathrm{m})$ & 1 & 8 & 1.0 & .40 & .60 & .53 & 4 & 1.2 & .80 & 1.0 & 1.0 \\
\hline
\end{tabular}

1 The difference in the median values were found to be statistically significant as described on page 6. 


\section{BURVIEW PARK POND}

Eagan I.D.:GP-1 USGS I.D.:44502093065100

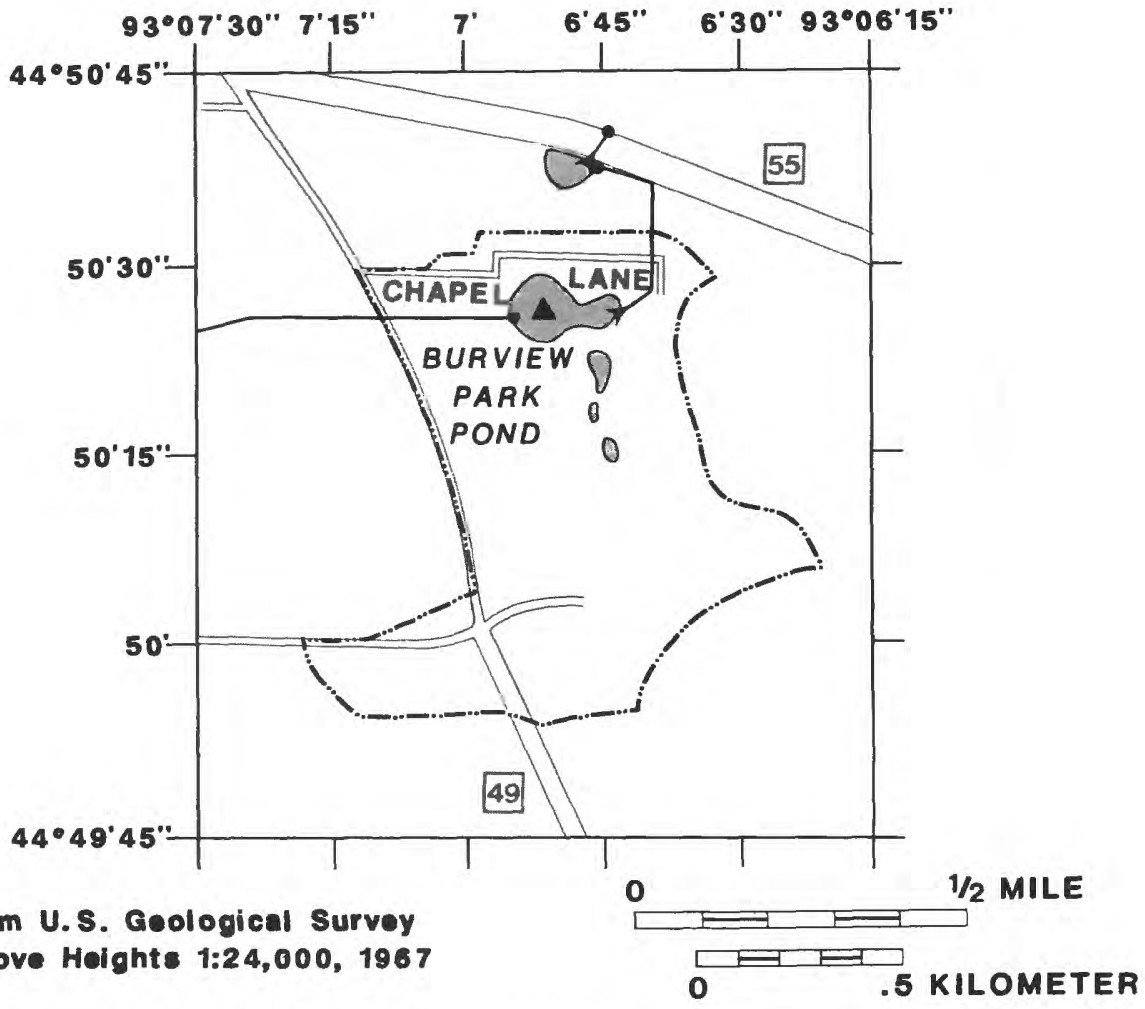

EXPLANATION

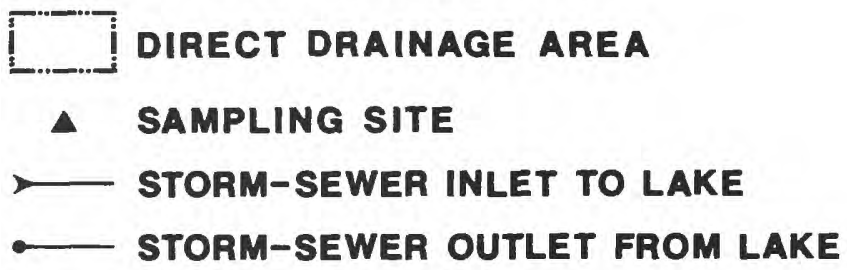

MORPHOMETRY

[See page 17 for a description of the lake and basin characteristics]

$\begin{array}{lcclr}\text { Direct Drainage Area (ac): } & 255 & \text { Average Depth, 1972-78 (ft): } & 6.0 \\ \text { Lake Area (ac): } & 9.3 \text { Average Depth, 1982-83 (ft): } & 6.1 \\ \text { Developed Area (ac): } & 59 \quad \text { Normal Elevation (ft): } & 806.5 \\ \text { Ponded Drainage Area (ac): } & 890 \quad \text { Maximum Elevation (ft): } & 820.0 \\ & & & \end{array}$




\section{QUALITY OF CEDAR GROVE POND CHANGED LITTLE OVER TIME}

The overall quality of Cedar Grove Pond has remained about the same since the 1972-78 sampling.

Cedar Grove Pond been situated in a highly urbanized setting during both this and the previous study. The effects of urbanization are apparent in the historical average concentration of chloride exceeding $30 \mathrm{mg} / \mathrm{L}$ and transparency being less than one-third of a meter. The wide range between the maximum and minimum chloride, phosphorus, and specific conductance during the previous study usually are associated with urban areas where large quantities of material will alternately accumulate on and be flushed from urban surfaces, alternately enriching and diluting runoff to lakes and ponds.

The measurements made in 1982-83 have a much lower range in values, but average values of these measurements are comparable to the 1972-78 measurements. Average chloride concentrations in the 1982-83 sampling were much lower than they had been previously, but the reduction was not statistically significant. It is possible that less chloride, probably road salt, was been washed into the pond during the 1982-83 sampling period. However, three samples probably do not accurately represent the average chloride concentration.

\section{WATER QUALITY}

[Samples taken near the surface of the lake.

See page 17 for descriptions of the constituents measured.]

\begin{tabular}{|c|c|c|c|c|c|c|c|c|c|c|}
\hline \multirow[b]{2}{*}{ Constituent } & \multicolumn{5}{|c|}{$1972-78$} & \multicolumn{5}{|c|}{$1982-83$} \\
\hline & N & Max & Min & Mean & Med & $\mathbf{N}$ & Max & Min & Mean & Med \\
\hline Temperature $\left({ }^{\circ} \mathrm{C}\right)$ & 15 & 29.0 & 0.0 & 15.9 & 16.0 & 5 & 28.0 & 0.5 & 17.3 & 23.0 \\
\hline \multicolumn{11}{|l|}{ Specific conductance } \\
\hline$\left(\mu \mathrm{S} / \mathrm{cm}\right.$ at $\left.25^{\circ} \mathrm{C}\right)$ & 15 & 357 & 82 & 208 & 180 & 3 & 188 & 168 & 181 & 187 \\
\hline Dissolved oxygen (mg/L) & 15 & 20.0 & 5.3 & 11.8 & 11.2 & 5 & 13.9 & 3.4 & 9.7 & 12.0 \\
\hline pH (standard units) & 15 & 10.3 & 7.4 & 8.2 & 9.2 & 5 & 10.2 & 7.1 & 7.7 & 8.8 \\
\hline Dissolved chloride (mg/L as C1) & 15 & 61.0 & 4.7 & 32.2 & 38.0 & 3 & 33.0 & 12.0 & 20.7 & 17.0 \\
\hline Total phosphorus (mg/L as P) & 13 & .52 & .06 & .22 & .15 & 3 & .16 & .10 & .14 & .15 \\
\hline Transparency (m) & 8 & .64 & .13 & .31 & .25 & 4 & .55 & .15 & .29 & .22 \\
\hline
\end{tabular}




\section{CEDAR GROVE POND}

\section{Eagan I.D.:AP-3 USGS I.D.:444821093124500}

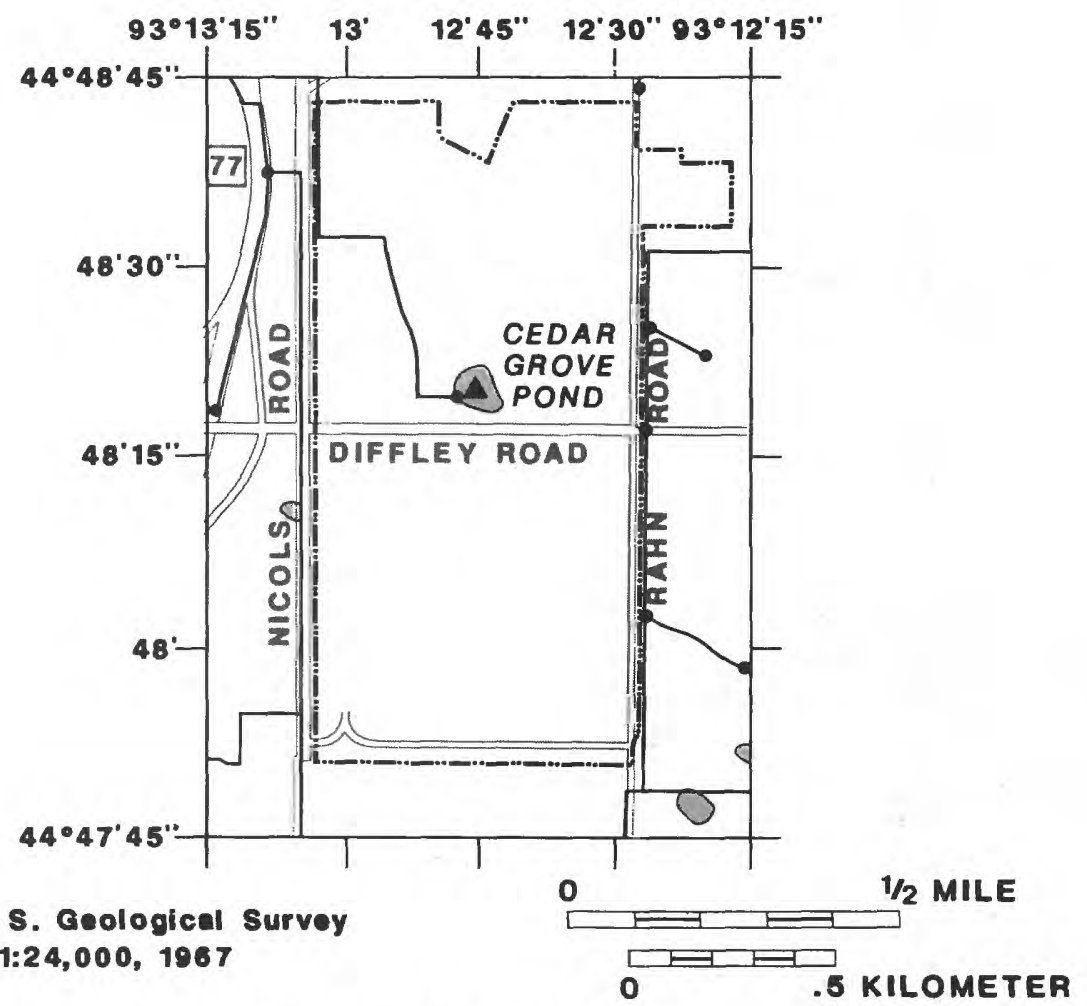

Base from U.S. Paul SW 1:24,000, 1967

o

5 KILOMETER

EXPLANATION

DIRECT DRAINAGE AREA

- SAMPLING SITE

- STORM-SEWER OUTLET FROM LAKE

MORPHOMETRY

[See page 17 for a description of the lake and basin characteristics]

Direct Drainage Area (ac): Lake Area (ac):

Developed Area (ac):

Ponded Drainage Area (ac):
320

3.1

317

0
Average Depth, 1972-78 (ft):

Average Depth, 1982-83 (ft):

Normal Elevation ( $f t$ ):

Maximum Elevation ( $f t$ ):
5.4

5.5

855.9

865.7

Maximum Measured Depth (ft):

8.5 
Donaldson's Pond

\section{INCREASED DEPTH IN POND MAY IMPROVE QUALITY}

The increased runoff to Donaldson's Pond has caused increased depth and stratification, which could trap phosphorus in the hypolimnion and reduce productivity.

The table of lake morphometry shows that the average depth of Donaldson's Pond has more than doubled since the previous study. This increased depth resulted from increased runoff to the lake. The maximum measured depth had reached 22 feet in August 1983. The increased depth-to-surface-area ratio resulted in the development of thermal stratification in the pond.

The illustration on page 31 shows a vertical profile measured in Donaldson's Pond in August 1983. It is apparent that the quality of the water near the surface of the lake (less than about 8 feet) was distinctly different from the quality of deeper water (greater than about 9 feet). The surficial water was well mixed, having a virtually constant temperature, conductance, and dissolved-oxygen concentration to a depth of 8 feet. Between 8 and 9 feet, however, the temperature dropped 6 degrees, the water became almost anoxic, and the conductance began to increase rapidly with depth. This region is called the thermocline, or metalimnion, and effectively forms a boundary between the surficial (epilimnetic) water and the deeper (hypolimnetic) water during the summer months.

The temperate climate of Minnesota encourages thermal stratification in summer, breakdown and mixing in fall, weak inverse stratification through winter, and a brief loss of stratification with return to thermal stratification in spring. The advantage stratification usually provides to deeper lakes, such as Holland and Fish, is that phosphorus used by epilimnetic phytoplankton is carried with their carcasses to the hypolimnion where it becomes trapped and unavailable to epilimnetic phytoplankton during the normally productive summer months. Two indicators of productivity in the summary table on the facing page, phosphorus and transparency, show that the productivity of Donaldson's Pond has declined between this study and the previous study.

The vertical profiles of Donaldson's Pond measured during the recent study show much greater conductance at depth than near the surface, as much as 4.9 times the surface conductance in February 1983. It is not known if this resulted from chemical dissolution near the bottom, a natural gradation from surface water to ground water, or the inflow of denser, cooler, highly conductive runoff water. A coefficient of determination $\left(\mathrm{R}^{2}\right)$ of 0.82 , statistically significant at greater than $\propto=0.01$ level, between 18 measurements of conductance and dissolved chloride concentration indicates that the chloride concentration near the bottom of Donaldson's Pond in February 1983 would have exceeded $250 \mathrm{mg} / \mathrm{L}$, the recommended limit for domestic consumption in Minnesota (Minnesota Pollution Control Agency, 1978). 
WATER QUALITY

[Samples taken near the surface of the lake.

See page 17 for descriptions of the constituents measured.]

\begin{tabular}{|c|c|c|c|c|c|c|c|c|c|c|}
\hline \multirow[b]{2}{*}{ Constituent } & \multicolumn{5}{|c|}{$1972-78$} & \multicolumn{5}{|c|}{$1982-83$} \\
\hline & $\mathbf{N}$ & Max & Min & Mean & Med & $\mathbf{N}$ & Max & Min & Mean & Med \\
\hline Temperature $\left({ }^{\circ} \mathrm{C}\right)$ & 15 & 27.0 & 1.0 & 16.1 & 16.0 & 5 & 25.5 & 3.0 & 16.5 & 21.5 \\
\hline \multicolumn{11}{|l|}{ Specific conductance } \\
\hline$\left(\mu \mathrm{S} / \mathrm{cm}\right.$ at $\left.25^{\circ} \mathrm{C}\right)$ & 15 & 372 & 114 & 255 & 255 & 5 & 270 & 207 & 247 & 253 \\
\hline Dissolved oxygen (mg/L) & 15 & 12.4 & 0.7 & 8.7 & 8.8 & 5 & 12.6 & 6.3 & 9.1 & 8.2 \\
\hline $\mathrm{pH}$ (standard units) & 15 & 9.1 & 7.2 & 7.8 & 8.2 & 5 & 9.1 & 7.6 & 8.1 & 8.5 \\
\hline Dissolved chloride (mg/L as C1) & 15 & 67.0 & 7.5 & 33.7 & 29.0 & 3 & 39.0 & 28.0 & 32.3 & 30.0 \\
\hline Total phosphorus (mg/L as P) & 13 & .20 & .02 & .08 & .06 & 3 & .08 & .03 & .05 & .05 \\
\hline Transparency $(\mathrm{m})$ & 8 & 1.0 & .35 & .65 & .60 & 4 & 1.3 & .52 & .90 & .90 \\
\hline
\end{tabular}




\section{DONALDSON'S POND}

Eagan I.D.:EP-1 USGS I.D.:445035093074600

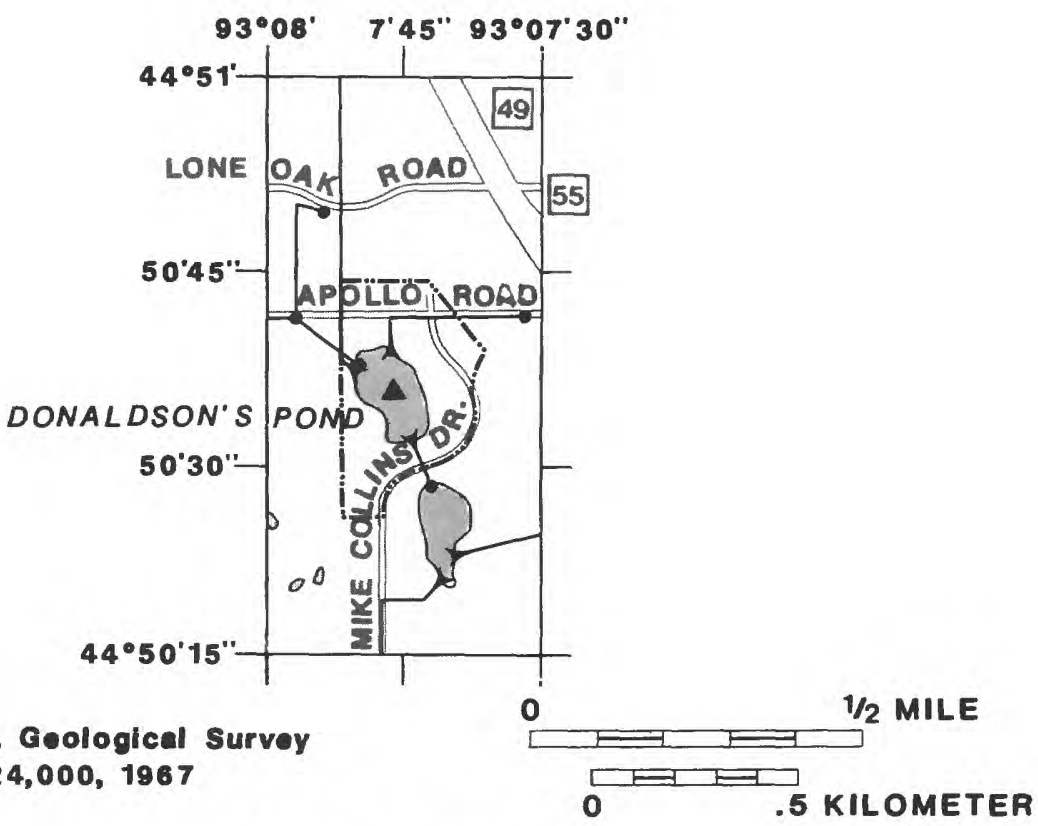

Base from U.S. Geological Survey

St. Paul SW 1:24,000, 1967

EXPLANATION

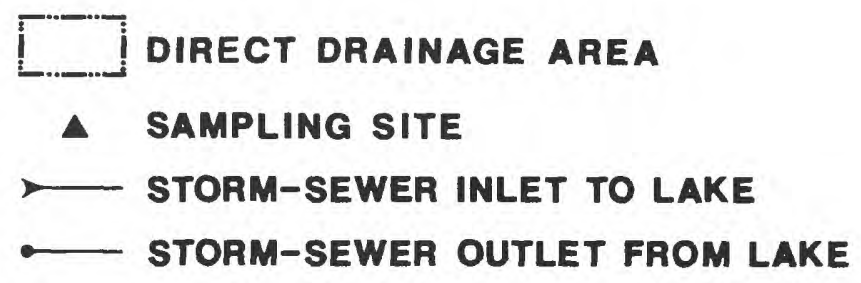

MORPHOMETRY

[See page 17 for a description of the lake and basin characteristics]

$\begin{array}{lcclr}\text { Direct Drainage Area (ac): } & 455 & \text { Average Depth, } 1972-78(\mathrm{ft}): & 7.5 \\ \text { Lake Area (ac): } & 8.4 & \text { Average Depth, 1982-83 (ft): } & 15.3 \\ \text { Developed Area (ac): } & 447 \quad \text { Normal Elevation (ft): } & 829.0 \\ \text { Ponded Drainage Area (ac): } & 1,606 & \text { Maximum Elevation (ft): } & 846.8 \\ & & & \end{array}$




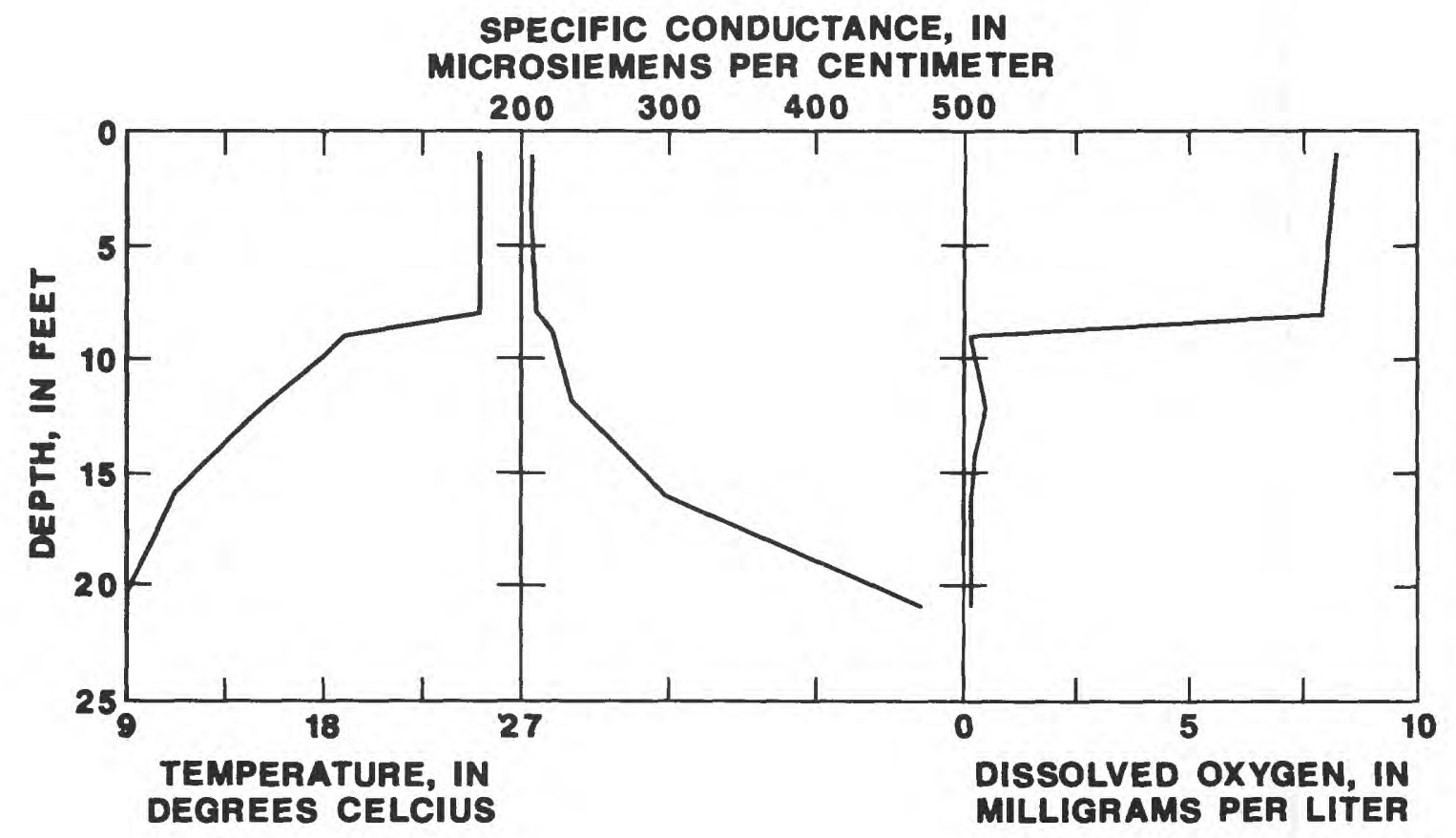




\title{
Fish Lake
}

\section{PHYSICAL CHANGES HAVE NOT CHANGED THE QUALITY \\ OF FISH LAKE}

\begin{abstract}
Increased drainage area and increased lake depth did not result in increased productivity.
\end{abstract}

Developed areas now contribute almost half the direct runoff received by Fish Lake and indirect runoff now is received from 3,600 additional acres. These changes in land use and drainage area have not caused a substantial change in the average transparency or total-phosphorus concentration, two indicators of lake productivity. Increased average lake depth, which could contribute phosphorus from vegetation decaying on inundated shorelines, did not result in measurably increased productivity.

Fish Lake is relatively deep, and during this study and the previous study was stratified during the summer. The lake has higher average concentrations of phosphorus in the hypolimnion than in the epilimnion; it would be expected to trap phosphorus in the hypolimnion preventing a major increase in productivity. The water-quality data on the facing page, however, do not show the increased hypolimnetic phosphorus expected, indicating that the lake has not been receiving the expected inflow of phosphorus or that the phosphorus is remaining bound in the lake sediments.

Phosphorus from direct runoff probably is intercepted by an intervening wetland that forms a sediment trap, however, inundated shoreline that is possible source of phosphorus that enriched epilimnetic waters in one of the other lakes studied did not measurably alter phosphorus concentrations in Fish Lake. The difference between lakes might be attributed to differences in shoreline morphology; the shoreline of Fish Lake is very steep and much of it is grassy rather than forested. This would result in minimal contact between the lake water and phosphorus-releasing leaf litter and humus. 
WATER QUALITY

See page 17 for descriptions of the constituents measured.

--, no data; <, less than]

\begin{tabular}{|c|c|c|c|c|c|c|c|c|c|c|c|}
\hline \multirow[b]{2}{*}{ Constituent } & \multirow{2}{*}{$\begin{array}{l}\text { Foot- } \\
\text { note }\end{array}$} & \multicolumn{5}{|c|}{$1972-78$} & \multicolumn{5}{|c|}{$1982-83$} \\
\hline & & $\mathbf{N}$ & Max & Min & Mean & Med & $\mathbf{N}$ & Max & Min & Mean & Med \\
\hline \multicolumn{12}{|c|}{ Samples Taken Near the Surface of the Lake } \\
\hline Temperature $\left({ }^{\circ} \mathrm{C}\right)$ & & 19 & 26.5 & 0.0 & 16.0 & 16.0 & 5 & 26.0 & 1.0 & 17.6 & 24.0 \\
\hline \multicolumn{12}{|l|}{ Specific conductance } \\
\hline$\left(\mu \mathrm{S} / \mathrm{cm}\right.$ at $\left.25^{\circ} \mathrm{C}\right)$ & & 17 & 322 & 175 & 228 & 225 & 5 & 300 & 183 & 228 & 205 \\
\hline Dissolved oxygen (mg/L) & & 19 & 11.4 & 4.7 & 8.9 & 8.8 & 5 & 13.0 & 3.4 & 7.7 & 7.4 \\
\hline pH (standard units) & & 16 & 10.2 & 7.3 & 8.0 & 8.2 & 5 & 8.7 & 6.6 & 7.2 & 7.9 \\
\hline Dissolved chloride (mg/L as C1) & & 17 & 20.0 & 4.5 & 12.5 & 13.0 & 5 & 18.0 & 14.0 & 16.2 & 16.0 \\
\hline Total phosphorus (mg/L as P) & & 17 & .08 & .01 & .02 & .02 & 5 & .02 & .02 & .02 & .02 \\
\hline Dissolved phosphorus (mg/L as P) & & 6 & .02 & $<.01$ & .01 & .02 & 4 & .02 & $<.01$ & .01 & .01 \\
\hline \multicolumn{12}{|l|}{ Nitrogen ( $\mathrm{mg} / \mathrm{L}$ as $\mathrm{N}$ ) } \\
\hline $\mathrm{NO}_{2}+\mathrm{NO}_{3}$ & & 8 & $<.1$ & $<.1$ & $<.1$ & $<.1$ & 5 & .36 & $<.1$ & .1 & $<.1$ \\
\hline $\mathrm{NH}_{4}^{2}+$ Organic & & 10 & 1.7 & .51 & .85 & .72 & 4 & 1.1 & .50 & .72 & .65 \\
\hline Suspended solids (mg/L) & & 8 & 106 & 0 & 16 & 2 & 4 & 14 & $<1$ & 4 & 1.2 \\
\hline Volatile suspended solids (mg/L) & & 0 & - & -- & -- & - & 4 & 14 & $<1$ & 4 & .8 \\
\hline Transparency (m) & & 9 & 4.4 & 2.2 & 3.0 & 2.6 & 4 & 3.2 & 1.8 & 2.6 & 2.7 \\
\hline \multicolumn{12}{|c|}{ Samples Taken Near the Bottom of the Lake } \\
\hline Temperature $\left({ }^{\circ} \mathrm{C}\right)$ & & 6 & 9.4 & 4.0 & 5.9 & 5.5 & 5 & 8.0 & 4.0 & 6.4 & 7.5 \\
\hline \multicolumn{12}{|l|}{ Specific conductance } \\
\hline$\left(\mu \mathrm{S} / \mathrm{cm}\right.$ at $\left.25^{\circ} \mathrm{C}\right)$ & & 6 & 458 & 289 & 349 & 340 & 5 & 425 & 288 & 359 & 354 \\
\hline Dissolved oxygen (mg/L) & & 6 & 0.4 & 0.1 & 0.2 & 0.1 & 5 & 11.6 & 0.1 & 2.9 & 1.0 \\
\hline $\mathrm{pH}$ (standard units) & & 6 & 7.1 & 7.0 & 7.1 & 7.1 & 5 & 8.2 & 6.1 & 6.7 & 7.3 \\
\hline Dissolved chloride (mg/L as C1) & & 6 & 21 & 14 & 18 & 18 & 5 & 30 & 17 & 21 & 18 \\
\hline Total phosphorus (mg/L as P) & & 6 & .74 & .01 & .17 & .04 & 5 & .08 & .03 & .05 & .04 \\
\hline $\begin{array}{l}\text { Dissolved phosphorus (mg/L as } \mathrm{P} \text { ) } \\
\text { Nitrogen (mg/L as } \mathrm{N} \text { ) }\end{array}$ & & 2 & .03 & .01 & -- & -- & 5 & .02 & $<.01$ & .01 & .01 \\
\hline $\mathrm{NO}_{2}+\mathrm{NO}_{3}$ & & 2 & $<.1$ & $<.1$ & -- & -- & 5 & .24 & $<.1$ & .12 & $<.1$ \\
\hline $\mathrm{NH}_{4}+$ Organic & & 4 & 6.5 & 1.9 & 3.9 & 3.6 & 5 & 3.3 & .60 & 1.4 & .90 \\
\hline Suspended solids (mg/L) & & 2 & 38 & 8 & -- & -- & 5 & 22 & 4 & 12 & 12 \\
\hline Volatile suspended solids (mg/L) & & 0 & -- & -- & -- & -- & 5 & 19 & $<1$ & 6.8 & 2 \\
\hline
\end{tabular}


This page is intentionally blank 


\section{FISH LAKE}

Eagan I.D.:JP-4 USGS I.D.: 444093095800

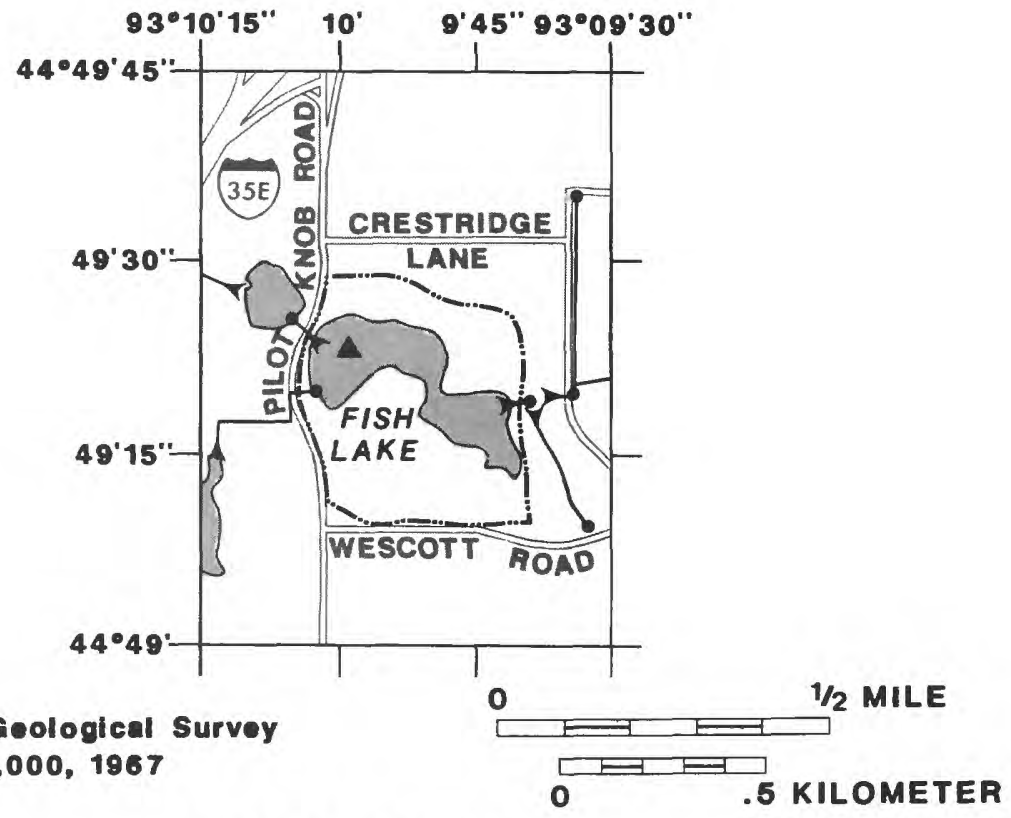

EXPLANATION

DIRECT DRAINAGE AREA

a SAMPLING site

STORM-SEWER INLET TO LAKE

- STORM-SEWER OUTLET FROM LAKE

MORPHOMETRY

[See page 17 for a description of the lake and basin characteristics]

Direct Drainage Area (ac): Lake Area (ac):

Developed Area (ac):

Ponded Drainage Area (ac):
67

31.4

28

3,647
Average Depth, 1972-78 (ft):

Average Depth, 1982-83 (ft):

Normal Elevation ( $f t$ ):

Maximum Elevation ( $f t$ ):

846.5 
Holland Lake

\section{INCREASED PRODUCTIVITY OBSERVED IN HOLLAND LAKE}

Statistically significant increases in dissolved-chloride
and total-phosphorus concentrations were observed in one
of Eagan's least productive and, hence, "cleanest" lakes.

Average concentrations of total phosphorus and dissolved chloride in surficial waters of Holland Lake were 50 percent higher during this study than during the previous study. The statistically significant increase in these constituents was accompanied by average transparency that declined by one third, a change that had an 89-percent chance of being significant. These changes indicate that productivity in Holland Lake has increased about 50 percent. Total phosphorus and dissolved chloride concentrations near the bottom of Holland lake were also higher during recent sampling, but these differences were not significant.

The increase in both chloride and phosphorus near the surface and near the bottom suggest that phosphorus is being carried into the lake with the chloride in runoff, but this might be coincidental. Holland Lake does receive runoff from Cliff Road (County Road 32), which probably would contain high concentrations of chloride but not phosphorus. A small housing development exists in the watershed of the lake, but is separated from the lake by forest and ponds. The housing development probably does not provide direct input to the lake, and no storm sewers presently bring direct runoff to the lake.

A likely source of the additional phosphorus is the dense forest surrounding almost the entire lake. Humus, decaying vegetation, and leaf litter of the forest floor can release large quantities of phosphorus, which ordinarily would be cycled back into the forest ecosystem. However, the rising level of Holland Lake has caused inundation of the surrounding forest floor (Don Burgardt of Bonestroo, Rosene, Anderlik, and Associates, Inc., oral commun., 1985), and field observations verify that extensive parts of the relatively flat, forested shoreline are under water. This could result in the release of large quantities of phosphorus to the lake.

If the source of phosphorus is the flooded forest floor, then Holland Lake probably will become less productive with improved transparency over time. The elevated level of Holland Lake may be a response to the long-term climatic variations that have caused increased levels in other local-area lakes and streams (Brown, 1985) so, eventually, the lake could return to lower levels.

City engineers may install an outlet from Holland Lake, preventing further inundation of the forest and possibly reducing the lake level (Don Burgardt of Bonestroo, Rosene, Anderlik, and Associates, Inc., oral commun., 1985). Holland Lake is a deep lake that develops strong thermal stratification in summer. The lake usually has an oxic hypolimnion, so, even if the lake level does not drop, the added phosphorus could become bound in the sediment, which would prevent continued eutrophication and, possibly, restore the lake to its original trophic state. 
This page is intentionally blank 
WATER QUALITY

See page 17 for descriptions of the constituents measured.

-- , no data; <, less than]

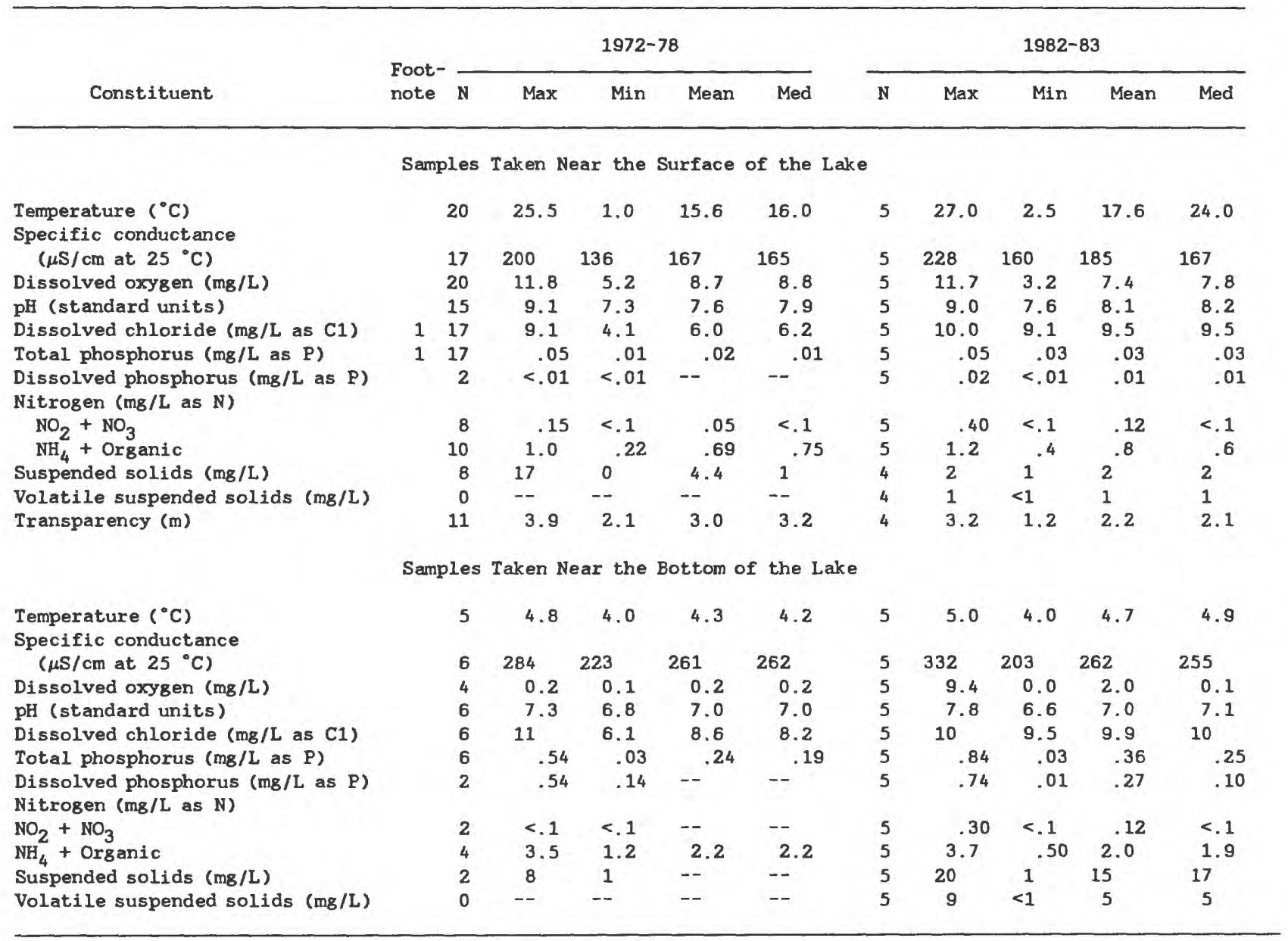

1 The difference in the median values were found to be statistically as described on page 6 . 


\section{HOLLAND LAKE}

Eagan I.D.:LP-38 USGS I.D.:444717093083100

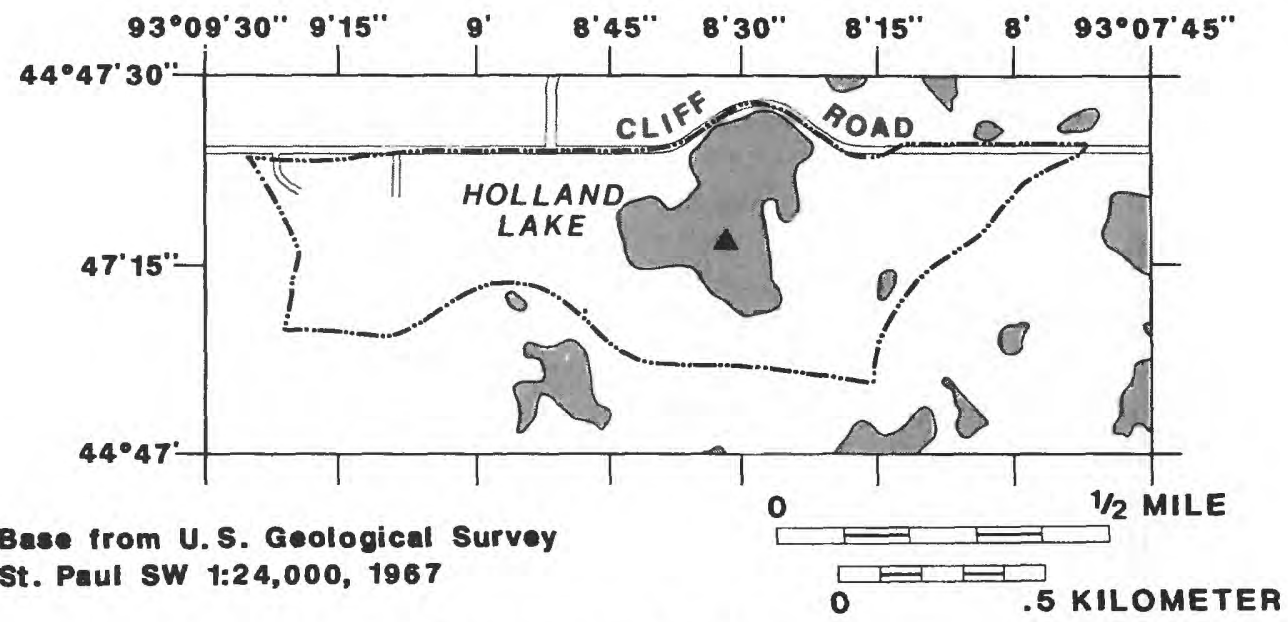

EXPLANATION

DIRECT DRAINAGE AREA

- SAMPLING SITE

MORPHOMETRY

[See page 17 for a description of the lake and basin characteristics]

$\begin{array}{lcclc}\text { Direct Drainage Area (ac): } & 206 & \text { Average Depth, 1972-78 (ft): } & 19.5 \\ \text { Lake Area (ac): } & 37.6 & \text { Average Depth, 1982-83 (ft): } & 23.2 \\ \text { Developed Area (ac): } & 29 & \text { Normal Elevation (ft): } & 865.0 \\ \text { Ponded Drainage Area (ac): } & 2,679 & \text { Maximum Elevation (ft): } & 878.5 \\ & & & & \end{array}$


Jensen Lake does not receive storm-sewered runoff and has no outlet during normal stages to encourage flushing, but total-phosphorus concentrations were significantly lower than during the previous study.

Land-1ocked Jensen Lake is in a setting very similar to that of Holland Lake, but is much shallower and does not exhibit distinct thermal stratification. While the total-phosphorus concentration of Holland Lake increased significantly, the total-phosphorus concentration in Jensen Lake decreased significantly. As Jensen Lake does not have an outlet at normal stages so that phosphorus can be flushed from the lake, another mechanism must be controlling phosphorus concentration.

The relatively high, 1972-78 average concentration of phosphorus may have been diluted by ground water flowing into Jensen Lake. The average lake depth during the previous study was about 4 feet, whereas the average depth for this study was nearly 6 feet. Measured phosphorus concentrations generally were highest when the lake was shallowest. Chloride concentration and conductance were not altered by the added water, so direct precipitation or runoff are unlikely to be factors, although precipitation amounts have been higher than normal. Increased average annual precipitation has raised ground-water levels and associated lake levels in the metropolitan area (Brown, 1985) and probably is altering lake and ground-water levels in Eagan. No data are available to show the assumed interrelation between ground water and the level of Jensen Lake, and the quality of the surficial ground water is unknown. Assuming the lake and surficial ground water have similar chloride concentrations and specific conductance, but the ground-water phosphorus concentration, which is in the dissolved form, is much lower, then ground-water inflow would dilute the total phosphorus concentrations in Jensen Lake without altering chloride concentrations and conductance.

WATER QUALITY

[Samples taken near the surface of the lake.

See page 17 for descriptions of the constituents measured.]

\begin{tabular}{|c|c|c|c|c|c|c|c|c|c|c|c|}
\hline \multirow[b]{2}{*}{ Constituent } & \multirow{2}{*}{$\begin{array}{l}\text { Foot- } \\
\text { note }\end{array}$} & \multicolumn{5}{|c|}{$1972-78$} & \multicolumn{5}{|c|}{$1982-83$} \\
\hline & & $\mathrm{N}$ & Max & Min & Mean & Med & $\mathbf{N}$ & Max & Min & Mean & Med \\
\hline $\begin{array}{l}\text { Temperature }\left({ }^{\circ} \mathrm{C}\right) \\
\text { Specific conductance }\end{array}$ & & 15 & 28.5 & 1.0 & 15.5 & 15.0 & 5 & 28.5 & 1.0 & 17.0 & 23.0 \\
\hline$\left(\mu \mathrm{S} / \mathrm{cm}\right.$ at $\left.25^{\circ} \mathrm{C}\right)$ & & 15 & 264 & 150 & 195 & 190 & 5 & 242 & 160 & 181 & 166 \\
\hline Dissolved oxygen (mg/L) & & 15 & 13.6 & 1.6 & 9.4 & 9.6 & 5 & 12.0 & 4.0 & 7.9 & 7.3 \\
\hline $\mathrm{pH}$ (standard units) & & 15 & 9.7 & 6.5 & 7.4 & 7.8 & 5 & 8.9 & 7.2 & 7.7 & 8.1 \\
\hline Dissolved chloride (mg/L as C1) & & 15 & 11.0 & 5.8 & 7.7 & 7.2 & 3 & 8.2 & 6.8 & 7.3 & 6.9 \\
\hline Total phosphorus (mg/L as $\mathrm{P}$ ) & 1 & 13 & .13 & .04 & .08 & .09 & 3 & .04 & .02 & .03 & .03 \\
\hline Transparency (m) & 2 & 8 & .91 & .25 & .51 & .48 & 4 & 1.8 & .48 & .85 & .56 \\
\hline
\end{tabular}

1 The difference in the median values were found to be statistically significant as described on page 6 .

2 One or more measurements for the 1982-83 period were limited by the depth to the lake bottom. The maximum, mean, and median values may be greater than those listed. 


\section{JENSEN LAKE}

Eagan I.D.:LP-12 USGS I.D.:444640093094700

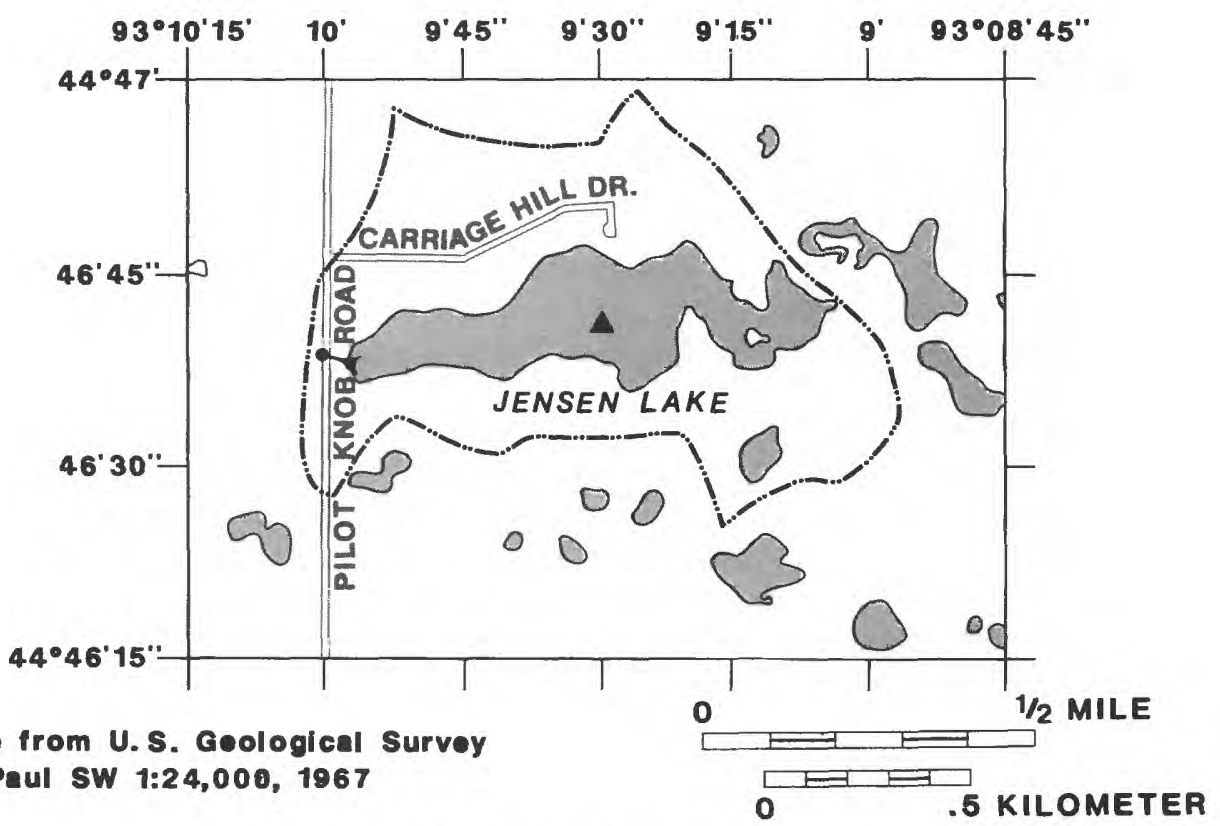

EXPLANATION

DIRECT DRAINAGE AREA

- SAMPLING SITE

- STORM-SEWER INLET TO LAKE

- STORM-SEWER OUTLET FROM LAKE

MORPHOMETRY

[See page 17 for a description of the lake and basin characteristics]

\begin{tabular}{lcclr}
\hline & & & & \\
Direct Drainage Area (ac): & 231 & Average Depth, 1972-78 (ft): & 4.0 \\
Lake Area (ac): & 52.4 & Average Depth, 1982-83 (ft): & 5.9 \\
Developed Area (ac): & 5.0 Normal Elevation (ft): & 921.2 \\
Ponded Drainage Area (ac): & 87 & Maximum Elevation (ft): & 925.0 \\
& & & \\
& & &
\end{tabular}


Lakeside Estates Lake

\section{URBAN RUNOFF MAY REDUCE PHOSPHORUS CONCENTRATION}

Significant increases in chloride and conductance accompanied by a decrease in the concentration of total phosphorus.

Phosphorus concentrations measured during this study were about half of those previously measured, and the probability is 90 -percent that this is not just the result of chance. The reduced concentration of total phosphorus was accompanied by statistically significant increases in conductance and dissolved chloride. Because conductance and, especially, chloride are associated with urban runoff that could contain dilute concentrations of phosphorus, it would seem that runoff has diluted or flushed out the high-phosphorus lake water.

A study in nearby Apple Valley, Minnesota (Have and others, 1981), showed that urban runoff to a lake contained elevated concentrations of chromium, copper, nickel, zinc, and arsenic. Sufficient concentrations of these metals can inhibit plant growth (Gough and others, 1979). It is possible that toxic concentrations of these metals have killed phytoplankton in Lakeside Estates Lake, improving transparency. Killed phytoplankton would carry phosphorus contained in their cells to the bottom, possibly reducing concentrations of total phosphorus in the lake water and reducing productivity.

The lower average total phosphorus concentration in Lakeside Estates Lake was not accompanied by increased transparency. An important measure of productivity, the Secchi-disk transparency was virtually unchanged between the two samplings. The recent TSI's for Lakeside Estates Lake in table 2 show that the Secchi-disk TSI was much higher than the TSI's for total phosphorus and chlorophyll a, indicating that the transparency may have been limited by particles other than algae suspended in the water. It also is possible that extra, unused phosphorus may have been measured during the previous study, possibly resulting from (1) phytoplankton consuming more phosphorus than required for normal metabolic functions, (2) toxic inhibition (natural or unnatural) of phytoplankton growth, or (3) phytoplankton growth limitation by an essential nutrient other than phosphorus.

WATER QUALITY

[Samples taken near the surface of the lake.

See page 17 for descriptions of the constituents measured.]

\begin{tabular}{|c|c|c|c|c|c|c|c|c|c|c|c|}
\hline \multirow[b]{2}{*}{ Constituent } & \multirow{2}{*}{$\begin{array}{l}\text { Foot- } \\
\text { note }\end{array}$} & \multicolumn{5}{|c|}{$1972-78$} & \multicolumn{5}{|c|}{$1982-83$} \\
\hline & & $\mathbf{N}$ & Max & Min & Mean & Med & $\mathbf{N}$ & $\operatorname{Max}$ & Min & Mean & Med \\
\hline Temperature $\left({ }^{\circ} \mathrm{C}\right)$ & & 15 & 26.0 & 0.0 & 15.7 & 19.0 & 5 & 26.6 & 1.0 & 16.8 & 24.0 \\
\hline \multicolumn{12}{|l|}{ Specific conductance } \\
\hline$\left(\mu \mathrm{S} / \mathrm{cm}\right.$ at $\left.25^{\circ} \mathrm{C}\right)$ & 1 & 15 & 220 & 110 & 183 & 184 & 5 & 316 & 210 & 242 & 228 \\
\hline Dissolved oxygen (mg/L) & & 15 & 12.2 & 4.4 & 9.0 & 8.4 & 5 & 11.9 & 5.6 & 7.9 & 6.6 \\
\hline $\mathrm{pH}$ (standard units) & & 15 & 9.6 & 7.4 & 8.0 & 8.2 & 5 & 9.3 & 7.4 & 8.0 & 8.4 \\
\hline Dissolved chloride (mg/L as C1) & 1 & 15 & 17.0 & 4.2 & 9.6 & 9.8 & 3 & 24.0 & 17.0 & 20.0 & 19.0 \\
\hline Total phosphorus (mg/L as P) & & 13 & .30 & .06 & .16 & .15 & 3 & .09 & .02 & .06 & .08 \\
\hline Transparency $(m)$ & & 8 & 1.1 & .20 & .48 & .36 & 4 & 1.1 & .24 & .50 & .34 \\
\hline
\end{tabular}

1 The difference in the median values were found to be statistically significant as described on page 6. 


\section{LAKESIDE ESTATES LAKE}

Eagan I.D.:LP-31 USGS I.D.:444738093065200

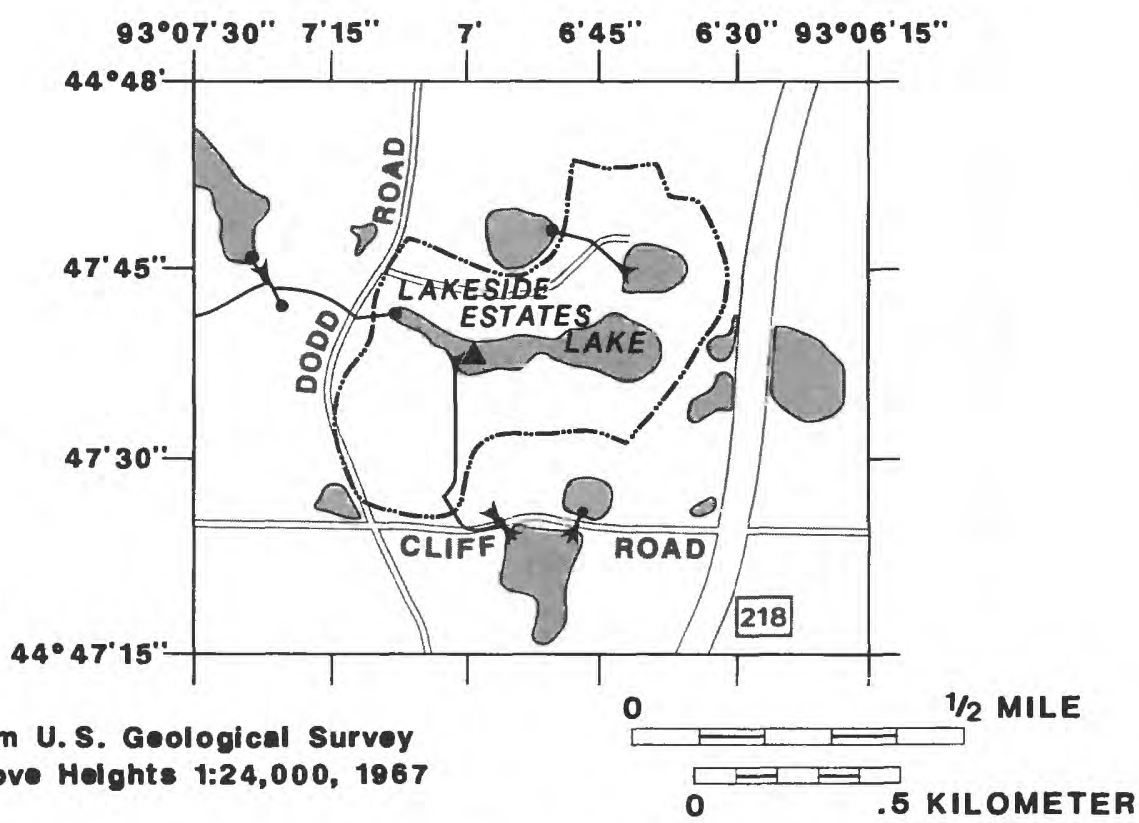

Base from U.S. Geological Survey

Inver Grove Helghts 1:24,000, 1967

EXPLANATION

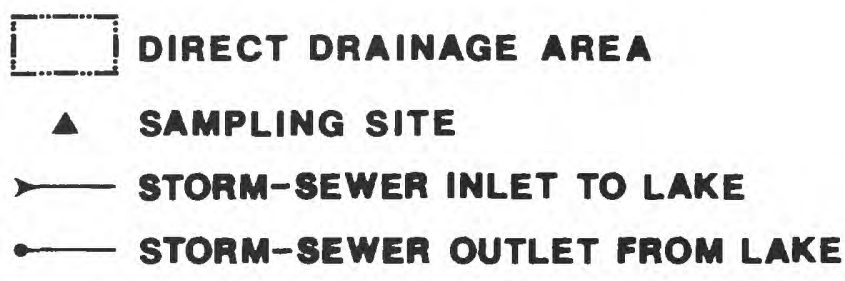

MORPHOMETRY

[See page 17 for a description of the lake and basin characteristics]

\begin{tabular}{lcclr}
\hline Direct Drainage Area (ac): & 121 & Average Depth, $1972-78(\mathrm{ft}):$ & 5.4 \\
Lake Area (ac): & 24.0 & Average Depth, 1982-83 (ft): & 6.6 \\
Developed Area (ac): & $51 \quad$ Normal Elevation (ft): & 907.8 \\
Ponded Drainage Area (ac): & 583 & Maximum Elevation (ft): & 910.0 \\
& & & \\
& & &
\end{tabular}




\section{Langhoven Pond}

\section{POND NEARLY FILLED WITH SEDIMENT}

Wide fluctuations in constituent concentrations show effects of enrichment and flushing, but pond may have lost storage capacity.

Langhoven Pond has received runoff from substantial areas of Eagan during both this and the previous study and chemically has changed little during that time. Although the differences were not significant, specific conductance and chloride were slightly higher during recent measurements and phosphorus was slightly lower. Contaminants and salts accumulated on urban surfaces are alternately washed into the pond and later flushed from the pond producing a wide range and scatter of concentration values that reduce the significance of differences in the average values.

The most notable trend in Langhoven Pond seems to be decreased depth. The average depth changed from 1.5 feet during the previous study to less than 1 foot during this study. The transparency, having several bottom-limited values, also declined from an average of 1.3 feet to about 0.8 foot. Because the pond has a controlled outlet structure and above-normal precipitation during the recent study should have kept the pond at or near that maximum elevation, the decreased depth is probably caused by sand and silt washing into the pond with runoff and settling to the bottom. The accumulating sediment is reducing the storage capacity of the pond.

Transparencies in Langhoven Pond were often bottom-limited, but were comparable to those measured in other nutrient-rich lakes in Eagan. Occasionally, however, readings have been limited by rooted growth near the bottom or a milky coloration observed in the water, not by phytoplankton.

\section{WATER QUALITY}

[Samples taken near the surface of the lake.

See page 17 for descriptions of the constituents measured.

-- , no data]

\begin{tabular}{|c|c|c|c|c|c|c|c|c|c|c|c|}
\hline \multirow[b]{2}{*}{ Constituent } & \multirow{2}{*}{$\begin{array}{l}\text { Foot- } \\
\text { note }\end{array}$} & \multicolumn{5}{|c|}{$1972-78$} & \multicolumn{5}{|c|}{$1982-83$} \\
\hline & & N & Max & Min & Mean & Med & N & $\operatorname{Max}$ & Min & Mean & Med \\
\hline Temperature $\left({ }^{\circ} \mathrm{C}\right)$ & & 15 & 30.0 & 0.5 & 16.1 & 18.0 & 4 & 28.0 & 11.5 & 20.6 & 21.5 \\
\hline \multicolumn{12}{|l|}{ Specific conductance } \\
\hline$\left(\mu \mathrm{S} / \mathrm{cm}\right.$ at $\left.25^{\circ} \mathrm{C}\right)$ & & 15 & 441 & 163 & 256 & 240 & 4 & 360 & 230 & 290 & 286 \\
\hline Dissolved oxygen (mg/L) & & 15 & 21.4 & 1.0 & 9.0 & 9.0 & 4 & 11.8 & 1.4 & 5.9 & 5.2 \\
\hline $\mathrm{pH}$ (standard units) & & 15 & 11.5 & 7.0 & 7.5 & 7.6 & 4 & 8.2 & 7.0 & 7.2 & 7.1 \\
\hline Dissolved chloride (mg/L as $\mathrm{C} 1$ ) & & 15 & 52.0 & 6.7 & 15.4 & 11.0 & 2 & 26.0 & 14.0 & -- & -- \\
\hline Total phosphorus (mg/L as P) & & 13 & .39 & .09 & .22 & .21 & 2 & .25 & .10 & -- & -- \\
\hline Transparency $(\mathrm{m})$ & 2 & 9 & .50 & .20 & .38 & .40 & 4 & .40 & .15 & .25 & .23 \\
\hline
\end{tabular}

2 One or more measurements for the $1972-78$ and $1982-83$ periods were limited by the depth to the lake bottom. The maximum, mean, and median values may be greater than those listed. 


\section{LANGHOVEN POND}

Eagan I.D.:AP-1 USGS I.D.:444859093122700

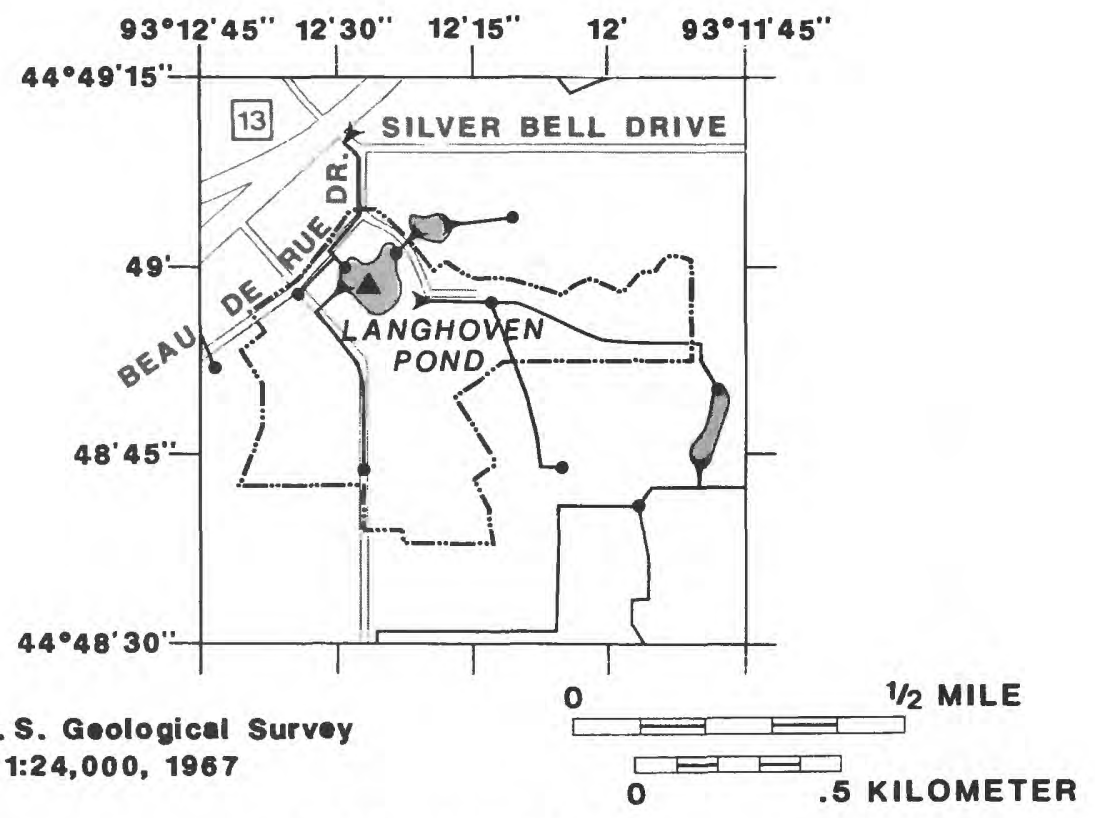

EXPLANATION

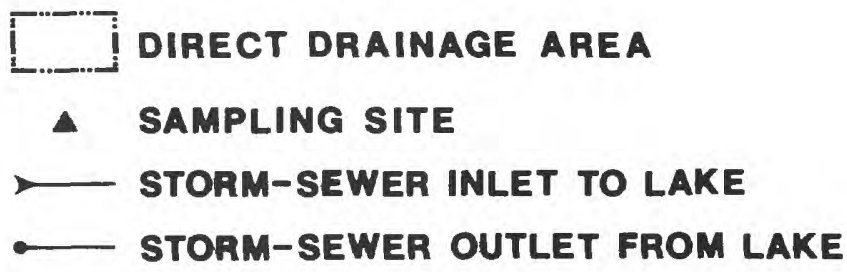

MORPHOMETRY

[See page 17 for a description of the lake and basin characteristics]

$\begin{array}{lcclr}\text { Direct Drainage Area (ac): } & 137 & \text { Average Depth, 1972-78 (ft): } & 1.5 \\ \text { Lake Area (ac): } & 4.5 & \text { Average Depth, 1982-83 (ft): } & .9 \\ \text { Developed Area (ac): } & 79 & \text { Normal Elevation (ft): } & 796.5 \\ \text { Ponded Drainage Area (ac): } & 1,761 & \text { Maximum Elevation (ft): } & 800.6 \\ & & & \\ & \text { Maximum Measured Depth (ft): } & 2.0 & \end{array}$




\section{REDUCED PHOSPHORUS DID NOT IMPROVE CLARITY}

The average concentration of phosphorus in Lemay Lake was about half of what it had been during the previous study, but transparency was virtually unchanged.

The total-phosphorus concentration declined by one-half since the study by Ayers and others (1980), a difference that had an 88 -percent chance of being significant. Whereas this should result in reduced productivity, the transparency, another indicator of productivity, was not measurably different from the previous readings. Many factors could, however, result in reduced phosphorus without reduced productivity since the previous study, including (1) phytoplankton consuming more phosphorus than required for normal metabolic functions, (2) toxic inhibition (natural or unnatural) of phytoplankton growth, or (3) limitation of phytoplankton growth by an essential nutrient other than phosphorus.

Specific conductance and chloride concentrations were virtually unchanged between the two study periods and indicate that Lemay Lake received urban runoff during both periods. Chloride was somewhat higher during the recent study, and tests give an 85 percent probability that this difference is significant.

\section{WATER QUALITY}

[Samples taken near the surface of the lake.

See page 17 for descriptions of the constituents measured.]

\begin{tabular}{|c|c|c|c|c|c|c|c|c|c|c|}
\hline \multirow[b]{2}{*}{ Constituent } & \multicolumn{5}{|c|}{$1972-78$} & \multicolumn{5}{|c|}{$1982-83$} \\
\hline & $\mathbf{N}$ & $\operatorname{Max}$ & Min & Mean & Med & N & $\operatorname{Max}$ & Min & Mean & Med \\
\hline Temperature $\left({ }^{\circ} \mathrm{C}\right)$ & 15 & 26.0 & 0.5 & 16.2 & 17.0 & 5 & 25.5 & 1.0 & 15.8 & 21.0 \\
\hline \multicolumn{11}{|l|}{ Specific conductance } \\
\hline$\left(\mu \mathrm{S} / \mathrm{cm}\right.$ at $\left.25^{\circ} \mathrm{C}\right)$ & 15 & 451 & 240 & 316 & 318 & 5 & 445 & 265 & 331 & 295 \\
\hline Dissolved oxygen (mg/L) & 15 & 13.2 & 5.6 & 10.0 & 10.8 & 4 & 11.9 & 3.1 & 7.5 & 7.5 \\
\hline pH (standard units) & 15 & 10.5 & 7.7 & 8.4 & 8.6 & 5 & 9.5 & 6.5 & 7.2 & 8.4 \\
\hline Dissolved chloride (mg/L as C1) & 15 & 34.0 & 17.0 & 25.6 & 25.0 & 3 & 33.0 & 31.0 & 32.0 & 32.0 \\
\hline Total phosphorus (mg/L as P) & 13 & .20 & .03 & .10 & .11 & 3 & .08 & .03 & .05 & .05 \\
\hline Transparency $(m)$ & 7 & .95 & .28 & .55 & .60 & 4 & 1.1 & .20 & .57 & .50 \\
\hline
\end{tabular}




\section{LEMAY LAKE}

\section{Eagan I.D.:DP-2 USGS I.D.:445042093094300}

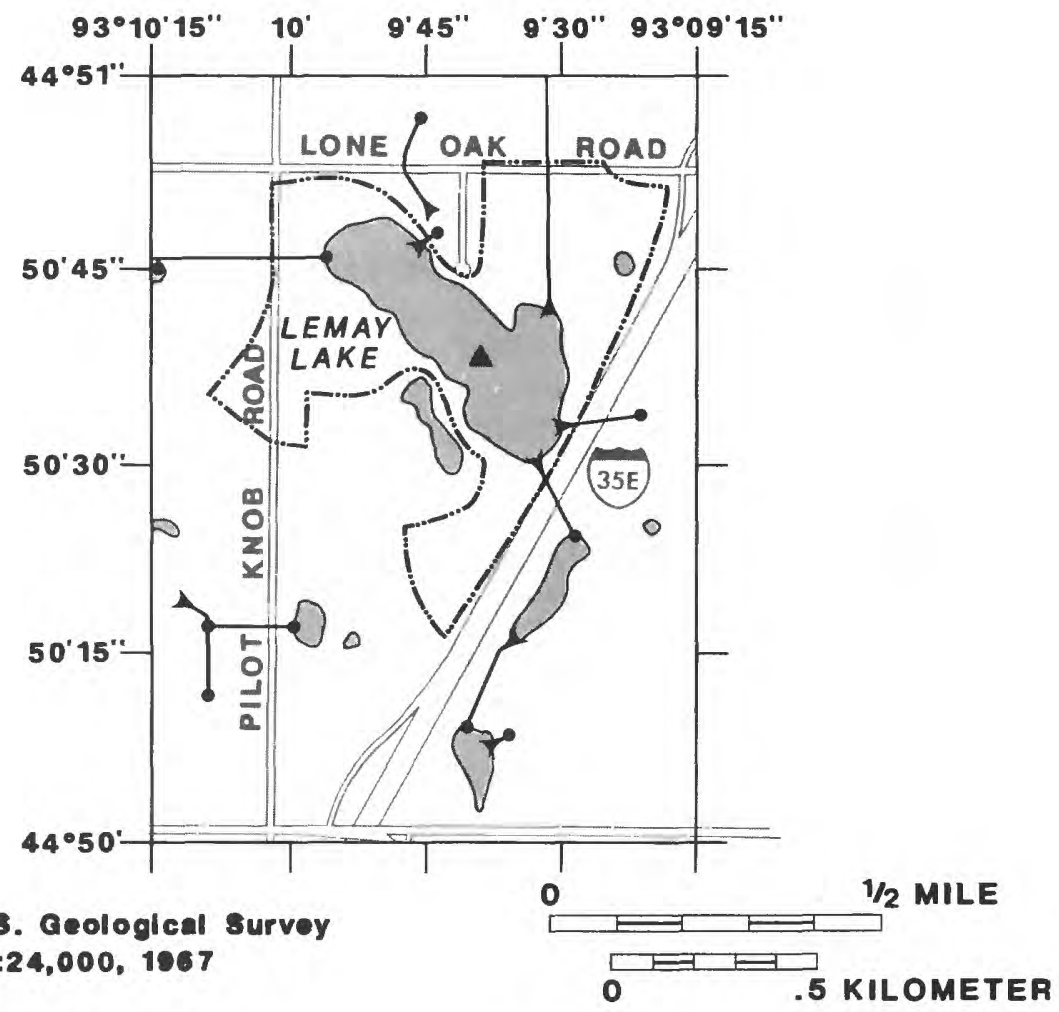

Base from U.8. Geological survey st. Paul sw 1:24,000, 1867

EXPLANATION

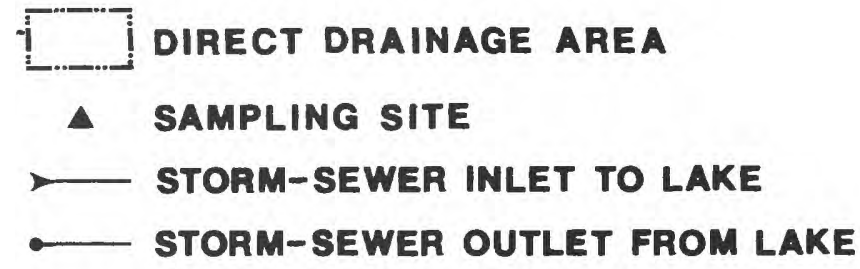

MORPHOMETRY

[See page 17 for a description of the lake and basin characteristics]

$\begin{array}{lclr}\text { Direct Drainage Area (ac): } & 262 & \text { Average Depth, 1972-78 (ft): } & 5.8 \\ \text { Lake Area (ac): } & 35.3 & \text { Average Depth, 1982-83 (ft): } & 6.4 \\ \text { Developed Area (ac): } & 185 & \text { Normal Elevation (ft): } & 874.0 \\ \text { Ponded Drainage Area (ac): } & 1,080 & \text { Maximum Elevation (ft): } & 878.0\end{array}$

Maximum Measured Depth (ft): 12.0 
McCarthy Lake

\section{IMPROVED QUALITY MAY RESULT FROM GROUND-WATER INFLOW}

Measurements suggest that productivity has declined, but dilution by urban runoff is not indicated.

Increased transparency and a reduced concentration of total phosphorus suggest that phytoplankton productivity has declined in McCarthy Lake. The probabilities are 89-percent and 72-percent that changes in transparency and total phosphorus concentration, respectively, are not just the result of chance. The 50-percent greater average lake depth suggests that natural phosphorus concentrations were diluted by water external to the lake, and improved transparency, although bottom limited, was one of the esthetic benefits. Dilution by rainwater or runoff is unlikely because conductance and average chloride concentration were virtually unchanged and, according to Bonestroo and others (1984), McCarthy Lake was not receiving inflow via the storm-sewer system.

It is likely that McCarthy Lake is being affected by changes in the water table similar to those described for Jensen Lake. Increased average annual precipitation has raised ground-water levels and associated lake levels in the metropolitan area (Brown, 1985) and probably is altering lake and ground-water levels in Eagan. No data are available to show the assumed interrelationship between ground water and the level of McCarthy Lake. If such a relation exists, however, conductance and chloride concentrations would remain similar and phosphorus concentrations would be lower because primarily dissolved and not particulate phosphorus would be transported by the ground water.

\section{WATER QUALITY}

ISamples taken near the surface of the lake.

See page 17 for descriptions of the constituents measured.]

\begin{tabular}{|c|c|c|c|c|c|c|c|c|c|c|c|}
\hline \multirow[b]{2}{*}{ Constituent } & \multirow{2}{*}{$\begin{array}{l}\text { Foot- } \\
\text { note }\end{array}$} & \multicolumn{5}{|c|}{$1972-78$} & \multicolumn{5}{|c|}{$1982-83$} \\
\hline & & $\mathbf{N}$ & $\operatorname{Max}$ & Min & Mean & Med & $\mathbf{N}$ & Max & Min & Mean & Med \\
\hline Temperature $\left({ }^{\circ} \mathrm{C}\right)$ & & 15 & 26.0 & 0.0 & 14.5 & 13.0 & 5 & 25.0 & 1.0 & 15.2 & 18.5 \\
\hline \multicolumn{12}{|l|}{ Specific conductance } \\
\hline$\left(\mu \mathrm{S} / \mathrm{cm}\right.$ at $\left.25^{\circ} \mathrm{C}\right)$ & & 15 & 475 & 221 & 293 & 285 & 5 & 510 & 230 & 311 & 275 \\
\hline Dissolved oxygen (mg/L) & & 15 & 16.3 & 0.5 & 7.8 & 7.5 & 5 & 13.0 & 0.8 & 4.7 & 3.1 \\
\hline $\mathrm{pH}$ (standard units) & & 15 & 9.5 & 7.2 & 7.7 & 8.0 & 5 & 7.9 & 6.3 & 6.9 & 7.6 \\
\hline Dissolved chloride (mg/L as C1) & & 15 & 9.8 & 2.3 & 5.6 & 5.5 & 3 & 10.0 & 3.7 & 6.7 & 6.3 \\
\hline Total phosphorus (mg/L as $\mathrm{P}$ ) & & 13 & .41 & .04 & .14 & .08 & 3 & .26 & .01 & .10 & .04 \\
\hline Transparency (m) & 2 & 7 & .91 & .30 & .57 & .61 & 3 & 1.7 & .70 & 1.0 & .70 \\
\hline
\end{tabular}

2 One or more measurements for the $1972-78$ and $1982-83$ periods were limited by the depth to the lake bottom. The maximum, mean, and median values may be greater than those listed. 


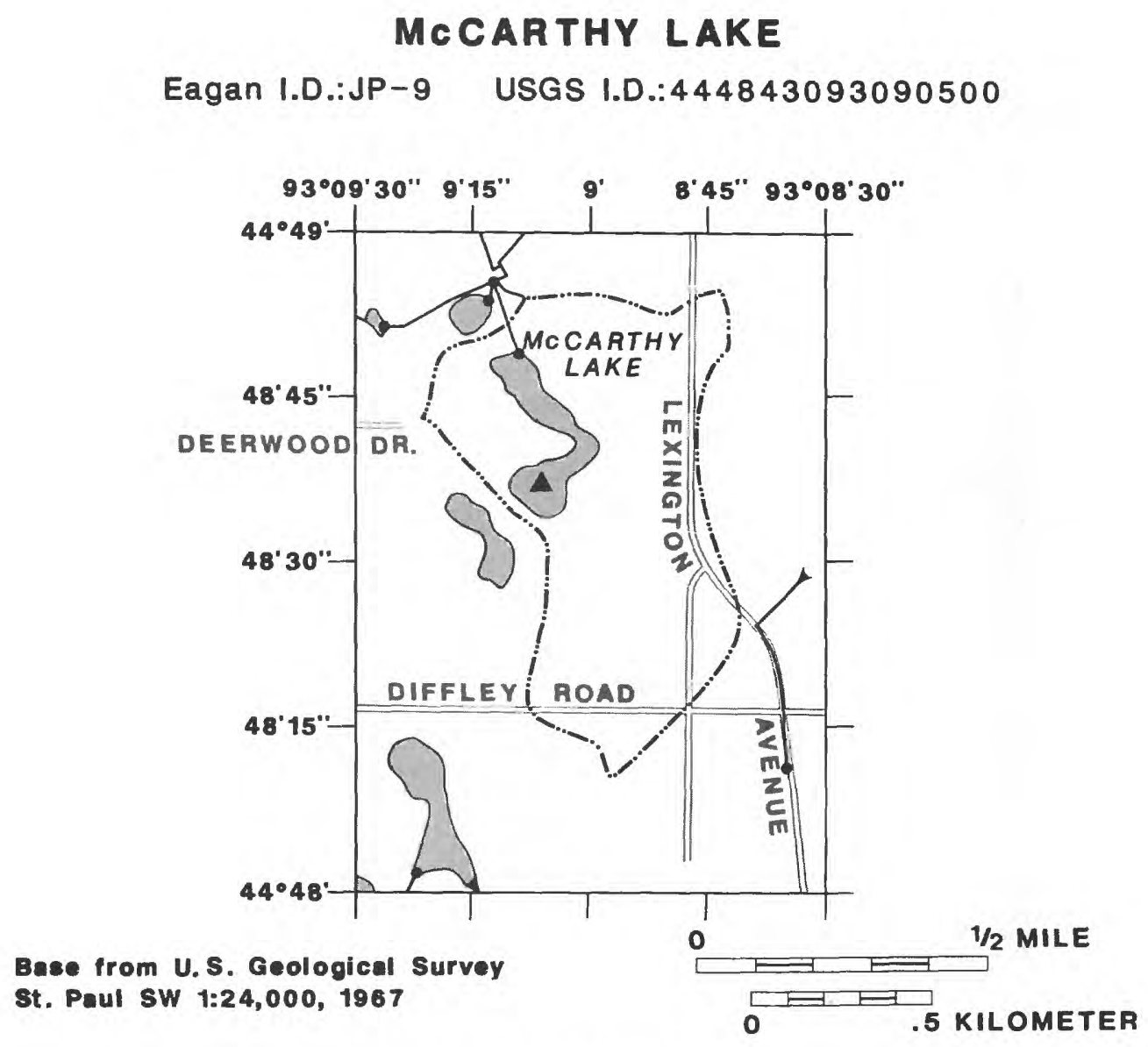

EXPLANATION

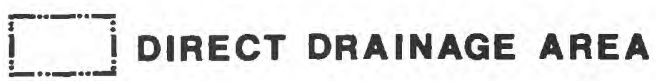

- SAMPLING SITE

- STORM-SEWER INLET TO LAKE

- STORM-SEWER OUTLET FROM LAKE

MORPHOMETRY

[See page 17 for a description of the lake and basin characteristics]

$\begin{array}{lclr}\text { Direct Drainage Area (ac): } & 227 & \text { Average Depth, 1972-78 (ft): } & 2.5 \\ \text { Lake Area (ac): } & 14.4 & \text { Average Depth, 1982-83 (ft): } & 3.9 \\ \text { Developed Area (ac): } & 14 & \text { Normal Elevation (ft): } & 818.7 \\ \text { Ponded Drainage Area (ac): } & 641 & \text { Maximum Elevation (ft): } & 830.0\end{array}$

Maximum Measured Depth (ft): 5.5 


\section{Shanahan Pond}

\section{PHOSPHORUS CONCENTRATION AND CONDUCTANCE SIGNIFICANTLY REDUCED}

Lake depth unchanged, but dilution of lake water is indicated.

Shanahan Pond, like most lakes in Eagan, probably is in contact with surficial aquifers and probably is a source of ground-water recharge. The topographic elevation of Shanahan Pond is high relative to most other lakes in Eagan and nearby Inver Grove Heights. Specific conductance and dissolvedchloride concentration were the lowest of any lakes sampled, which indicates that water in the lake has been in contact with soluble minerals for a relatively short period of time, and probably is affected more by precipitation than by ground water.

The statistically significant reduction in phosphorus concentration and conductance could result from dilution by precipitation water having a low concentration of dissolved solids. Shanahan Pond was not receiving sewered runoff when sampled (Bonestroo and others, 1984) and the low, unaltered chloride concentration suggests that dilute urban runoff had not affected the lake. Diluting water might be expected to raise the level in this land-locked lake, but the average depth of Shanahan Pond has remained virtually unchanged.

Precipitation in the Twin Cities Metropolitan Area has been above normal during recent years (Brown, 1985), which probably increases recharge to the ground-water system and temporarily raises the level of the lake. Other factors also may conceal or mitigate the expected increase in depth of the lake.

1. The large standard deviation for measurements of lake depth, 1.5 for both the historical and recent measurements, indicates that the actual average lake depth could be substantially different from the values listed on the facing page.

2. Assuming Shanahan Pond is located near the recharge area for the surficial aquifer, the pond might rise rapidly in response to precipitation, then return to a normal level as the water recharges the ground-water system.

WATER QUALITY

[Samples taken near the surface of the lake.

See page 17 for descriptions of the constituents measured.

-- , no data]

\begin{tabular}{|c|c|c|c|c|c|c|c|c|c|c|c|}
\hline \multirow[b]{2}{*}{ Constituent } & \multirow{2}{*}{$\begin{array}{l}\text { Foot- } \\
\text { note }\end{array}$} & \multicolumn{5}{|c|}{$1972-78$} & \multicolumn{5}{|c|}{$1982-83$} \\
\hline & & $\mathbf{N}$ & Max & Min & Mean & Med & $\mathbf{N}$ & $\operatorname{Max}$ & Min & Mean & Med \\
\hline Temperature $\left({ }^{\circ} \mathrm{C}\right)$ & & 10 & 26.5 & 2.0 & 16.6 & 19.5 & 5 & 26.5 & 2.0 & 16.9 & 21.8 \\
\hline \multicolumn{12}{|l|}{ Specific conductance } \\
\hline$\left(\mu \mathrm{S} / \mathrm{cm}\right.$ at $\left.25^{\circ} \mathrm{C}\right)$ & 1 & 10 & 146 & 98 & 122 & 124 & 5 & 110 & 68 & 96 & 102 \\
\hline Dissolved oxygen (mg/L) & & 10 & 12.4 & 0.7 & 8.5 & 8.8 & 5 & 11.4 & 5.4 & 8.3 & 8.2 \\
\hline pH (standard units) & & 10 & 11.0 & 7.0 & 7.6 & 8.1 & 5 & 9.4 & 6.5 & 7.1 & 8.1 \\
\hline Dissolved chloride (mg/L as C1) & & 10 & 4.7 & 2.7 & 3.5 & 3.3 & 3 & 4.4 & 2.7 & 3.5 & 3.4 \\
\hline Total phosphorus (mg/L as $P$ ) & 1 & 10 & .14 & .05 & .09 & .08 & 3 & .07 & .03 & .05 & .05 \\
\hline Transparency $(m)$ & & 2 & 1.8 & .74 & -- & -- & 4 & 2.1 & .46 & .91 & .54 \\
\hline
\end{tabular}

1 The difference in the median values were found to be statistically significant as described on page 6 . 


\section{SHANAHAN POND}

\section{Eagan I.D.:FP-8 USGS I.D.:445115093062100}

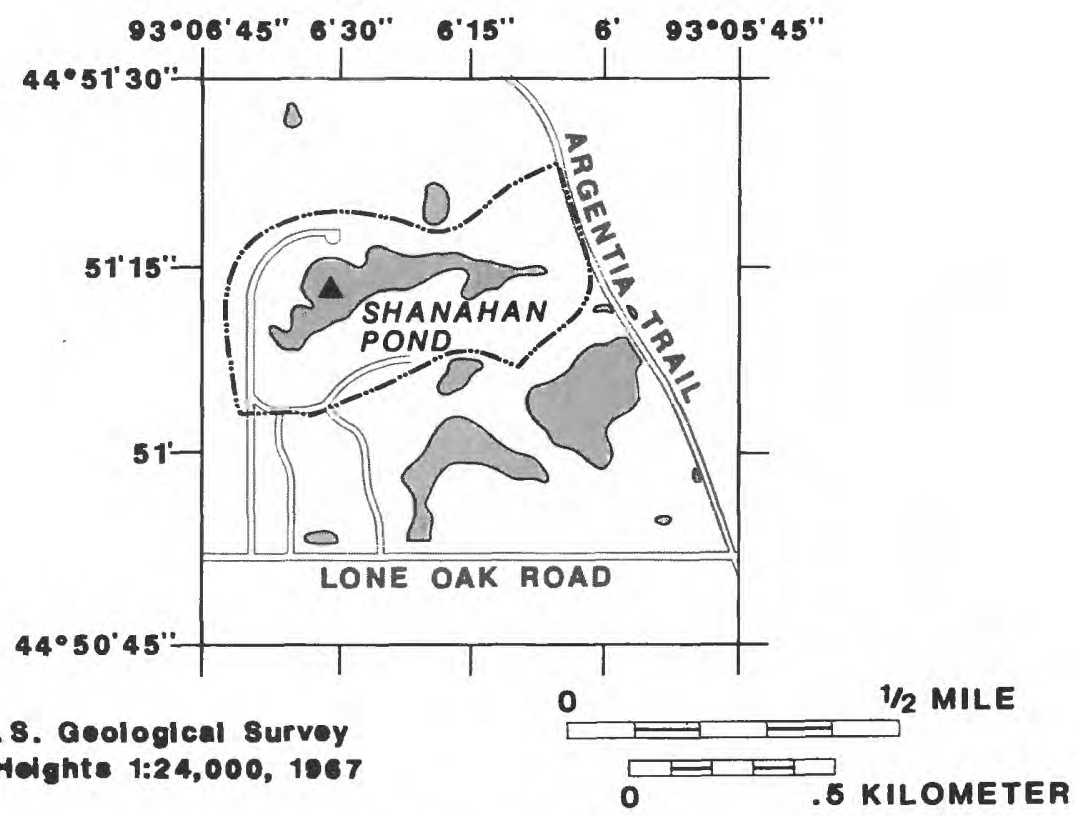

Base from U.8. Geological Survey

Inver Orove Helghts 1:24,000, 1967

\section{EXPLANATION}

\section{DIRECT DRAINAGE AREA}

\section{a SAMPLING Site}

\section{MORPHOMETRY}

[See page 17 for a description of the lake and basin characteristics]

$\begin{array}{lcll}\text { Direct Drainage Area (ac): } & 85 & \text { Average Depth, 1972-78 (ft): } & 4.9 \\ \text { Lake Area (ac): } & 10.9 & \text { Average Depth, 1982-83 (ft): } & 4.9 \\ \text { Developed Area (ac): } & 0.6 & \text { Normal Elevation (ft): } & 875.6 \\ \text { Ponded Drainage Area (ac): } & 318 & \text { Maximum Elevation (ft): } & 878.0\end{array}$

Maximum Measured Depth (ft): 9.0 


\section{Slater's Acres Pond}

\section{REDUCED PRODUCTIVITY MAY BE RELATED TO URBAN RUNOFF}

\section{Significantly improved transparency is accompanied by significantly higher conductance, indicating that urban runoff may be affecting the trophic status of the pond.}

Transparency measurements indicate that productivity in Slater's Acres Pond has been reduced. The improvement in average Secchi-disk transparency is double what it had been during the previous study, and is statistically significant, although some readings were limited by the depth of the pond. The improved transparency probably results from a reduction in the average concentration of the growth-limiting nutrient phosphorus, a difference that had an 86 -percent probability of not being the result of chance.

The change in the quality of Slater's Acres Pond indicates that it has been receiving urban runoff. The significant increase in conductance since the previous study probably is the result of salts dissolved from urban surfaces and washed into the pond. The increase in the average concentration of dissolved chloride, although not significant, is probably a good indicator of urban runoff received by the lake.

A study in nearby Apple Valley, Minnesota (Have and others, 1981), showed that urban runoff to a lake contained elevated concentrations of chromium, copper, nickel, zinc, and arsenic. Sufficient concentrations of these metals can inhibit plant growth (Gough and others, 1979). It is possible that toxic concentrations of these metals have killed phytoplankton in Slater's Acres Pond, improving transparency. Killed phytoplankton would carry phosphorus contained in their cells to the bottom, possibly reducing concentrations of total phosphorus in the pond resulting in the apparent reduction in productivity.

The increased average depth of Slater's Acres Pond could be the result of (1) increased runoff to the pond with limited seepage out of it and (or) (2) long-term excess precipitation that is affecting other lakes and ground water in the Twin Cities area (Brown, 1985) also may be raising the leve1 of Slater's Acres Pond.

\section{WATER QUALITY}

[Samples taken near the surface of the lake.

See page 17 for descriptions of the constituents measured.]

\begin{tabular}{|c|c|c|c|c|c|c|c|c|c|c|c|}
\hline \multirow[b]{2}{*}{ Constituent } & \multirow{2}{*}{$\begin{array}{l}\text { Foot- } \\
\text { note }\end{array}$} & \multicolumn{5}{|c|}{$1972-78$} & \multicolumn{5}{|c|}{$1982-83$} \\
\hline & & $\mathrm{N}$ & $\operatorname{Max}$ & $\operatorname{Min}$ & Mean & Med & $\mathbf{N}$ & $\operatorname{Max}$ & Min & Mean & Med \\
\hline Temperature $\left({ }^{\circ} \mathrm{C}\right)$ & & 15 & 27.0 & 0.0 & 15.0 & 12.0 & 5 & 28.0 & 2.0 & 17.3 & 22.0 \\
\hline \multicolumn{12}{|l|}{ Specific conductance } \\
\hline$\left(\mu \mathrm{S} / \mathrm{cm}\right.$ at $\left.25^{\circ} \mathrm{C}\right)$ & 1 & 15 & 207 & 91 & 135 & 118 & 5 & 226 & 130 & 185 & 195 \\
\hline Dissolved oxygen (mg/L) & & 15 & 14.2 & 0.0 & 8.6 & 9.5 & 5 & 13.7 & 2.1 & 8.7 & 9.1 \\
\hline $\mathrm{pH}$ (standard units) & & 15 & 9.5 & 6.8 & 7.4 & 7.4 & 5 & 9.3 & 7.1 & 7.7 & 8.4 \\
\hline Dissolved chloride (mg/L as C1) & & 15 & 23.0 & 4.8 & 11.9 & 9.0 & 3 & 20.0 & 16.0 & 18.0 & 18.0 \\
\hline Total phosphorus (mg/L as $\mathrm{P}$ ) & & 13 & .27 & .04 & .18 & .16 & 3 & .22 & .02 & .09 & .03 \\
\hline Transparency $(\mathrm{m})$ & 2 & 8 & 1.5 & .20 & .70 & .66 & 4 & 2.0 & 1.1 & 1.5 & 1.3 \\
\hline
\end{tabular}

1 The difference in the median values were found to be statistically significant as described on page 6 .

2 One or more measurements for the $1972-78$ and $1982-83$ periods were limited by the depth to the lake bottom. The maximum, mean, and median values may be greater than those listed. 


\section{SLATER'S ACRES POND}

\section{Eagan I.D.:AP-34 USGS I.D.:444652093131000}

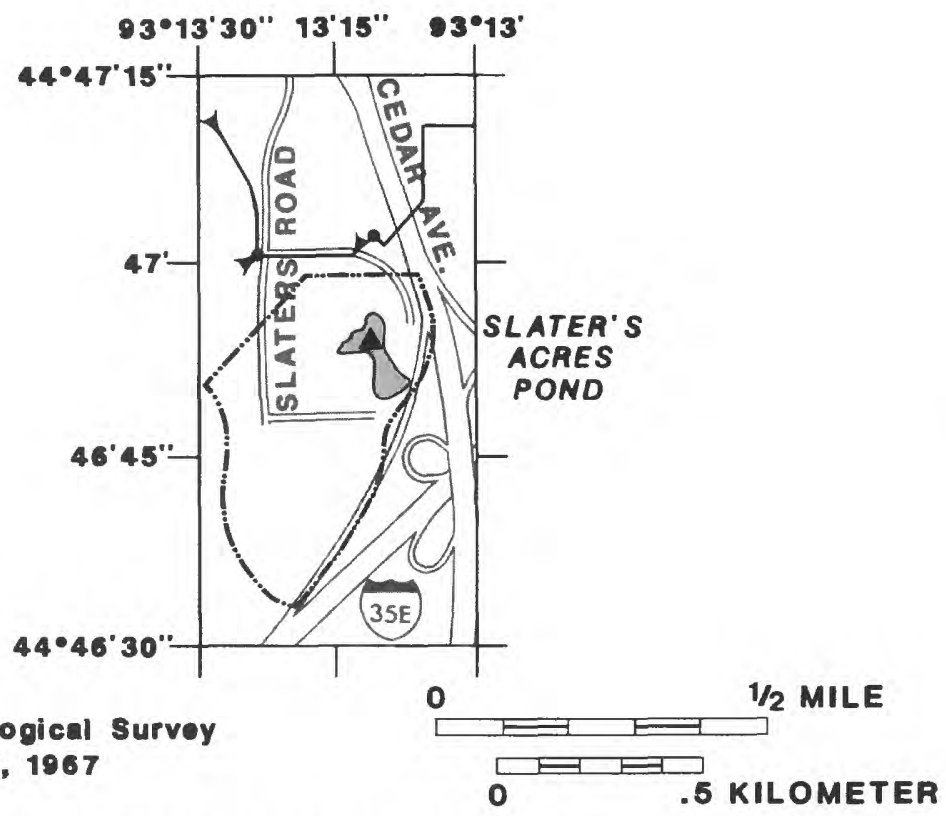

EXPLANATION

Base from U.S. Geological Survey St. Paul SW 1:24,000, 1967

\section{DIRECT DRAINAGE AREA}

a SAMPLING SITE

STORM-SEWER INLET TO LAKE

- STORM-SEWER OUTLET FROM LAKE

MORPHOMETRY

[See page 17 for a description of the lake and basin characteristics]

$\begin{array}{lcclr}\text { Direct Drainage Area (ac): } & 61 & \text { Average Depth, 1972-78 (ft): } & 3.5 \\ \text { Lake Area (ac): } & 3.5 \text { Average Depth, 1982-83 (ft): } & 5.4 \\ \text { Developed Area (ac): } & 13 & \text { Normal Elevation (ft): } & 934.0 \\ \text { Ponded Drainage Area (ac): } & 0 & \text { Maximum Elevation (ft): } & 938.8 \\ & & & \\ & \text { Maximum Measured Depth (ft): } 7.0\end{array}$


Thomas Lake

URBAN RUNOFF PROBABLY AFFECTING THOMAS LAKE

Significantly higher specific conductance and dissolved-chloride concentrations indicate that urban runoff has altered the chemistry of Thomas Lake.

The watershed of Thomas Lake is only about 7-percent developed for urban land use. Indirectly, however, the lake receives drainage from almost 4,500 acres of land having a large amount of urban development.

Ponding of runoff before it enters Thomas Lake should reduce the amount of suspended material entering the lake, but ponding would not reduce the concentration of dissolved material in the water. The average concentration of suspended solids was lower during this study, and there is a 76-percent probability that this difference is significant. Concentrations of total phosphorus did not increase over previous values, and, because phosphorus usually is attached to sediment particles, the phosphorus load potentially added by runoff may have settled out. Dissolved salts measured for this study, however, were much more concentrated. Dissolved chloride, commonly associated with urban runoff, and conductance, a gross measure of salts dissolved in the water, were significantly higher than was measured during the study by Ayers and others (1980).

The average depth of Thomas Lake was slightly less than during the study by Ayers and others (1980), whereas the depth of most lakes increased. This could indicate that the lake is already at its maximum 908-foot elevation and additional water is released through the outlet. It is also possible that the lake has risen, yet partially filled with eroded soil because freshly deposited coarse sediment probably eroded from the direct drainage area has been observed near the inlet at the east side of the lake.

WATER QUALITY

[Samples taken near the surface of the lake.

See page 17 for descriptions of the constituents measured.

-- , no data; <, less than]

\begin{tabular}{|c|c|c|c|c|c|c|c|c|c|c|c|}
\hline \multirow[b]{2}{*}{ Constituent } & \multirow{2}{*}{$\begin{array}{l}\text { Foot- } \\
\text { note }\end{array}$} & \multicolumn{5}{|c|}{$1972-78$} & \multicolumn{5}{|c|}{$1982-83$} \\
\hline & & $\mathrm{N}$ & $\operatorname{Max}$ & Min & Mean & Med & $\mathrm{N}$ & $\operatorname{Max}$ & Min & Mean & Med \\
\hline Temperature $\left({ }^{\circ} \mathrm{C}\right)$ & & 17 & 29.5 & 0.0 & 15.5 & 15.0 & 5 & 26.5 & 1.5 & 16.9 & 22.1 \\
\hline \multicolumn{12}{|l|}{ Specific conductance } \\
\hline$\left(\mu \mathrm{S} / \mathrm{cm}\right.$ at $\left.25^{\circ} \mathrm{C}\right)$ & 1 & 17 & 230 & 175 & 195 & 190 & 5 & 267 & 210 & 224 & 215 \\
\hline Dissolved oxygen (mg/L) & & 17 & 13.1 & 5.6 & 9.7 & 9.9 & 5 & 13.4 & 3.8 & 8.1 & 6.1 \\
\hline $\mathrm{pH}$ (standard units) & & 17 & 9.9 & 7.1 & 7.8 & 8.5 & 5 & 10.0 & 7.4 & 8.0 & 8.8 \\
\hline Dissolved chloride ( $\mathrm{mg} / \mathrm{L}$ as $\mathrm{C} 1$ ) & 1 & 17 & 23.0 & 14.0 & 17.7 & 16.0 & 5 & 32.0 & 23.0 & 27.2 & 28.0 \\
\hline Total phosphorus (mg/L as $\mathrm{P}$ ) & & 15 & .18 & .04 & .12 & .13 & 5 & .20 & .05 & .13 & .13 \\
\hline Dissolved phosphorus ( $\mathrm{mg} / \mathrm{L}$ as $\mathrm{P}$ ) & & 6 & .03 & $<.01$ & .02 & .02 & 5 & .04 & $<.01$ & .02 & .01 \\
\hline \multicolumn{12}{|l|}{ Nitrogen (mg/L as $\mathrm{N}$ ) } \\
\hline $\mathrm{NO}_{2}+\mathrm{NO}_{3}$ & & 8 & .11 & $<.1$ & .06 & $<.1$ & 5 & .17 & $<.1$ & .07 & $<.1$ \\
\hline $\mathrm{NH}_{4}^{2}+$ Organic & & 10 & 6.6 & 1.5 & 3.6 & 3.2 & 5 & 4.0 & .8 & 2.4 & 1.7 \\
\hline Suspended solids (mg/L) & & 8 & 84 & 7 & 24 & 15 & 5 & 36 & 2 & 13 & 9 \\
\hline Volatile suspended solids (mg/L) & & 0 & -- & -- & -- & -- & 4 & 10 & $<1$ & 4.4 & 3.5 \\
\hline Transparency (m) & & 10 & 1.1 & .20 & .49 & .38 & 4 & 1.2 & .20 & .52 & .35 \\
\hline
\end{tabular}

1 The difference in the median values were found to be statistically significant as described on page 6. 


\section{THOMAS LAKE}

\section{Eagan I.D.:BP-7 USGS I.D.:444735093100800}

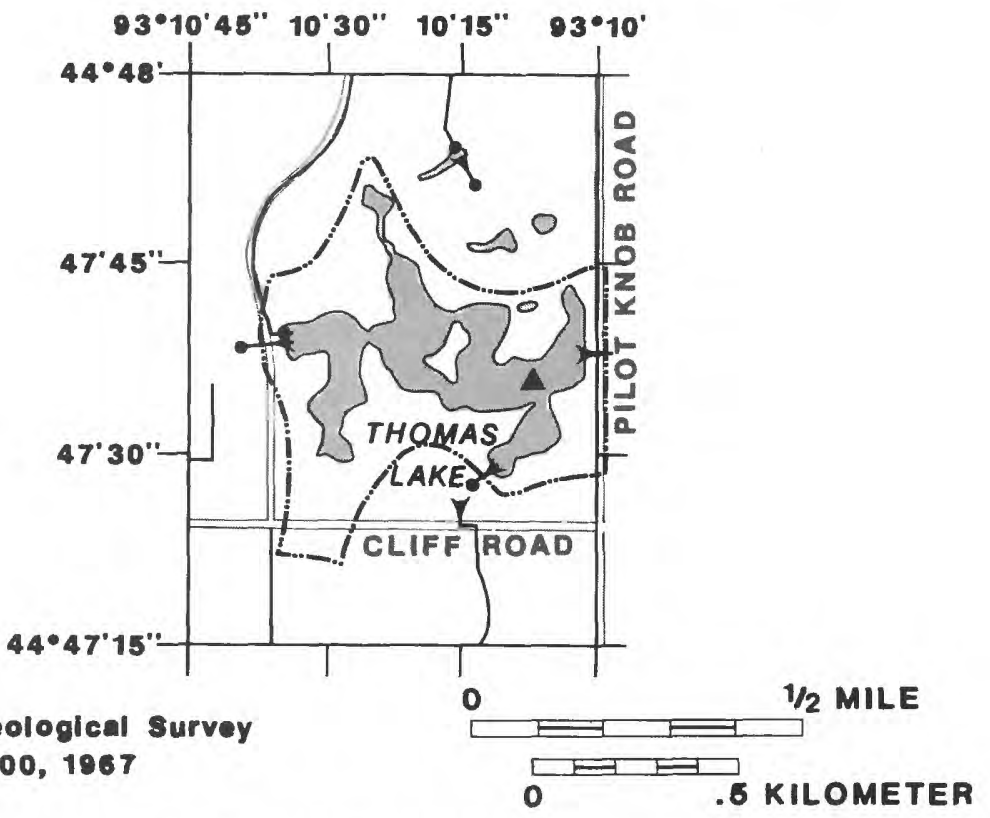

Base from U. 8. Ceological survey

St. Paul SW 1:24,000, 1967

EXPLANATION

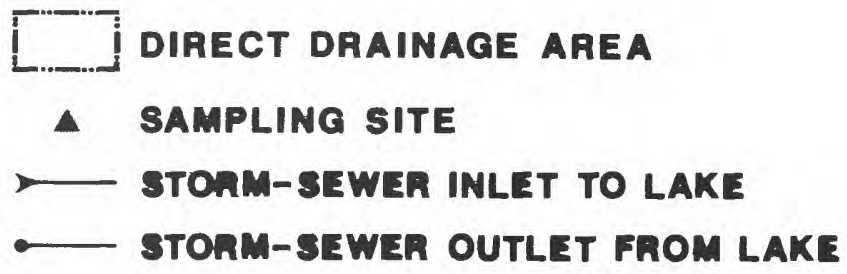

MORPHOMETRY

[See page 17 for a description of the lake and basin characteristics]

$\begin{array}{lclr}\text { Direct Drainage Area (ac): } & 218 & \text { Average Depth, 1972-78 (ft): } & 4.9 \\ \text { Lake Area (ac): } & 41.1 & \text { Average Depth, 1982-83 (ft): } & 4.5 \\ \text { Developed Area (ac): } & 15 & \text { Normal Elevation (ft): } & 904.2 \\ \text { Ponded Drainage Area (ac): } & 4,491 & \text { Maximum Elevation (ft): } & 908.0\end{array}$

Maximum Measured Depth (ft): 9.2 


\section{Wilderness Lake}

\section{WILDERNESS LAKE MAY BE FLUSHED BY URBAN RUNOFF}

Significantly higher chloride and specific conductance measured, but productivity apparently decreased.

Phytoplankton productivity appears to be much lower in Wilderness Lake than during the study by Ayers and others (1980). The average transparency of the lake was three times greater and the maximum transparency was more than 1.5 meters during this study, with an 80-percent probability that the difference was significant. The concentration of total phosphorus was much lower during this study, with an 84-percent probability that this difference was significant.

Reduced productivity may be the result of flushing the lake by urban runoff. Sixty percent of the direct drainage area is urbanized, and significantly higher chloride concentrations and specific conductance indicate that the lake has been receiving urban runoff. Evidence of urban runoff combined with reduced phosphorus and improved transparency suggest that runoff water with a low concentration of phosphorus is diluting or flushing the lake, although other chemicals in runoff could produce this effect.

A study in nearby Apply Valley, Minnesota (Have and others, 1981), showed that urban runoff to a lake contained elevated concentrations of chromium, copper, nickel, zinc, and arsenic. Sufficient concentrations of these metals can inhibit plant growth (Gough and others, 1979). It is possible that toxic concentrations of these metals have killed phytoplankton in Wilderness Lake, improving transparency. Killed phytoplankton would carry phosphorus contained in their cells to the bottom, possibly reducing concentrations of total phosphorus in the lake water and, in turn, reducing productivity.

The average depth of Wilderness Lake did not increase as would be expected from added runoff and rising water tables. The average measured depth actually decreased 0.4 foot--the same decline measured in adjacent Thomas Lake. The close proximity of Thomas and Wilderness Lakes and similar changes in depth suggest that the lakes are hydraulically connected, possibly through a partially submerged culvert, or that both lakes have experienced excessive sedimentation caused by erosion from the direct drainage area.

WATER QUALITY

[Samples taken near the surface of the lake.

See page 17 for descriptions of the constituents measured.]

\begin{tabular}{|c|c|c|c|c|c|c|c|c|c|c|c|}
\hline \multirow[b]{2}{*}{ Constituent } & \multirow{2}{*}{$\begin{array}{l}\text { Foot- } \\
\text { note }\end{array}$} & \multicolumn{5}{|c|}{$1972-78$} & \multicolumn{5}{|c|}{$1982-83$} \\
\hline & & N & $\operatorname{Max}$ & Min & Mean & Med & $\mathrm{N}$ & $\operatorname{Max}$ & Min & Mean & Med \\
\hline Temperature $\left({ }^{\circ} \mathrm{C}\right)$ & & 15 & 29.0 & 2.0 & 15.6 & 15.0 & 5 & 26.0 & 2.5 & 17.6 & 23.5 \\
\hline \multicolumn{12}{|l|}{ Specific conductance } \\
\hline$\left(\mu \mathrm{S} / \mathrm{cm}\right.$ at $\left.25^{\circ} \mathrm{C}\right)$ & 1 & 15 & 193 & 123 & 161 & 160 & 5 & 263 & 187 & 237 & 254 \\
\hline Dissolved oxygen (mg/L) & & 15 & 13.9 & 5.7 & 9.1 & 8.6 & 5 & 13.1 & 3.3 & 9.0 & 9.8 \\
\hline $\mathrm{pH}$ (standard units) & & 15 & 11.4 & 7.2 & 7.8 & 8.3 & 5 & 9.9 & 7.4 & 8.0 & 8.4 \\
\hline Dissolved chloride ( $m g / L$ as $C 1$ ) & 1 & 15 & 17.0 & 5.8 & 10.9 & 11.0 & 3 & 33.0 & 20.0 & 26.3 & 26.0 \\
\hline Total phosphorus (mg/L as $\mathrm{P}$ ) & & 13 & .32 & .02 & .15 & .13 & 3 & .09 & .04 & .07 & .07 \\
\hline Transparency (m) & & 8 & .64 & .18 & .38 & .30 & 4 & 1.6 & .21 & .95 & 1.0 \\
\hline
\end{tabular}

1 The difference in the median values were found to be statistically significant as described on page 6 . 


\section{WILDERNESS LAKE}

Eagan I.D.:BP-8 USGS I.D.444745093095700

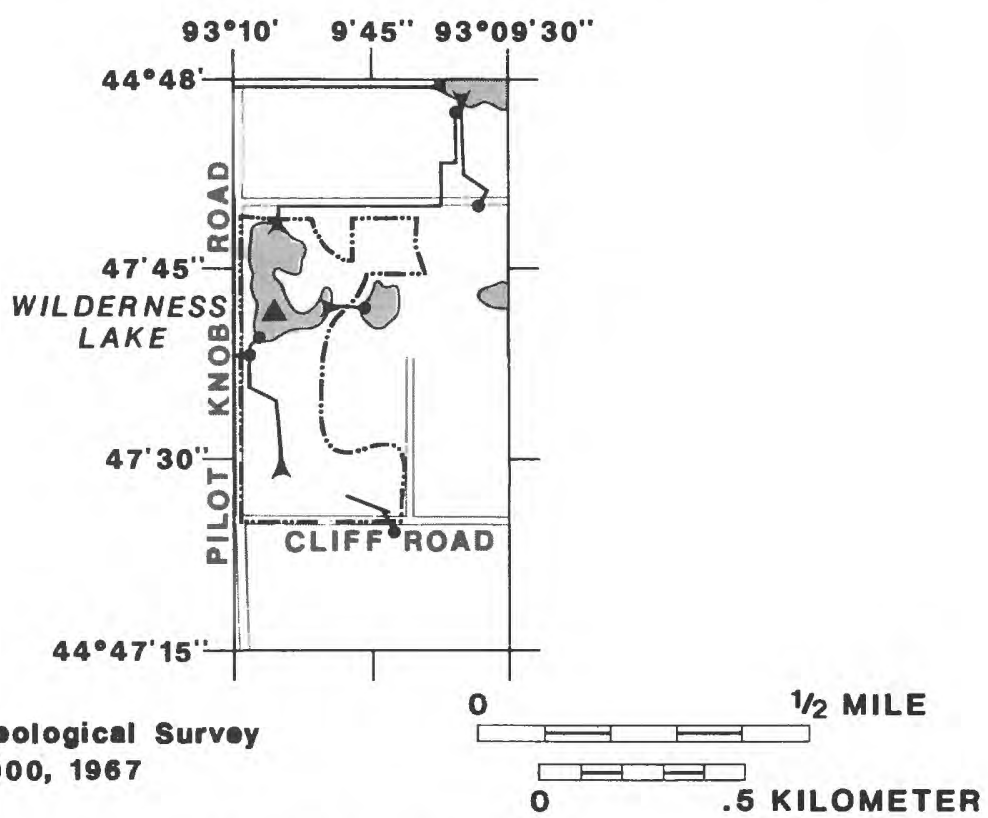

EXPLANATION

DIRECT DRAINAGE AREA

- SAMPLING SITE

— STORM-8EWER INLET TO LAKE

- - STORM-SEWER OUTLET FROM LAKE

MORPHOMETRY

[See page 17 for a description of the lake and basin characteristics]

$\begin{array}{lclr}\text { Direct Drainage Area (ac): } & 55 & \text { Average Depth, 1972-78 (ft): } & 4.8 \\ \text { Lake Area (ac): } & 9.8 & \text { Average Depth, 1982-83 (ft): } & 4.4 \\ \text { Developed Area (ac): } & 35 & \text { Normal Elevation (ft): } & 905.2 \\ \text { Ponded Drainage Area (ac): } & 707 & \text { Maximum Elevation (ft): } & 908.0\end{array}$

Maximum Measured Depth (ft): 8.0 


\section{EVALUATION OF LAKE-QUALITY MODELS}

The 10 parametric phosphorus-prediction models described in the report by Ayers and others (1980) are listed in table 3. Development of the first four models is described in Ayers and others (1980), and development of the remaining six models is described in the reference given with the model. The derivation of input data for the models is explained in the Methods and Approach section of this report.

Table 4 shows the median phosphorus concentration determined for each of the lakes sampled in this study, and the corresponding phosphorus concentrations computed by the 10 lake-quality models. The median value is used as an indicator of central tendency, because one or two unusually high phosphorus concentrations measured in some of the lakes resulted in high meanphosphorus concentrations that could be misleading. The first three models developed for the lakes (Ayers and others, 1980) and the Walker (1977) model do not seem to accurately predict the concentrations measured in this study. Several models--namely, the land-locked lobound and hibound models (Reckhow, 1979) and the Chapra-Tarapchak (1976) model--were reasonably accurate predictors of phosphorus concentration for a few lakes. The best predictor seems to be the deep-lake model, which was developed by Ayers and others (1980) for Holland and Fish Lakes. In addition to predicting the phosphorus concentration of Fish Lake to within 5 percent, the deep lake model predicts the concentration within 20 percent in 4 of the 14 relatively shallow lakes.

It is apparent in table 3 that, for certain lakes, the phosphorus-1oading models consistently overestimate concentrations in the lakes. Small lakes with large drainage areas such as Cedar Grove and Langhoven are flushed many times in most years and probably lose phosphorus to downstream areas. The drainage areas for some lakes including Donaldson and Burview are undergoing rapid development, and it is possible that phosphorus concentrations will approach the values indicated by the models.

Many important influences on the quality of the Eagan lakes are not addressed by these models, including (1) ground-water flux through the lakes, (2) recycling of phosphorus in the lake sediments, (3) interactions between fish, zooplankton, and phytoplankton, and (4) the interaction between phytoplankton and rooted aquatic plants.

The most significant effect on the quality of the lakes, however, probably is the installation of the storm-sewer system. Virtually every lake and pond in the city is part of the system and will receive runoff from an area much larger than the natural drainage area. It is not surprising that models developed primarily for land-locked lakes do not accurately predict concentrations in lakes that now have inflows and outflows.

Accurate phosphorus-loading models for the Eagan lakes might be developed if additional presently unquantified parameters that describe effects on lake quality were included. Major additional parameters that need to be quantified include (1) ground-water flux (recharge-discharge) and nutrient concentrations, (2) magnitude of storms, (3) antecedent soil moisture, (4) seasonal availability of phosphorus in runoff, (5) nutrient-assimilation capacity of 
Table 3.--Results of phosphorus-prediction models

\section{Models from Ayers and others, 1980}

(1) Regression model $-\mathrm{P}=(3,635,381+92,297 \mathrm{DEVP}-590,429 \mathrm{LOGVOL})^{1 / 3}$

(2) Sigma model -- P $=$ LOADP $\left[Z^{*}(\mathrm{SIGMA}+\mathrm{RHO})\right] \ldots$ where: $\mathrm{SIGMA}=\exp (-2.25+3.2 \mathrm{QSLOG})$; if $\mathrm{QS}<3.51$ SIGMA $=3+1.28 \mathrm{RHO} ;$ IF $\mathrm{QS}>3.50$

(3) Retention model -- $\mathrm{P}=(\mathrm{LOADP} / Z) * \mathrm{RC} \ldots$ where: $\mathrm{RC}=\exp (-0.4124-1.1778 \mathrm{RHOLOG})$

(4) Deep lake model -- $P=$ LOADP/ $\left[Z^{\star}(2 Q S+R H O)\right]$

\section{Other published models}

(5) Chapra-Tarapchak (1976) model -- $P=($ LOADP/QS $) *(1-R V) \ldots$ where: $R V=12.4 /(12.4+Q S)$

(6) Jones-Bachmann (1976) model -- P = LOADP/ $\left[Z^{*}(0.65+\right.$ RHO $\left.)\right]$

(7) Reckhow (1979) oxic model -- P = LOADP/ $[18 Z /(10+z)+1.05 Q S * \exp (0.012 Q S)]$

(8) Walker (1977) model -- P = LOADP/ $\mathrm{QS}^{\star}\left[1+0.824(1 / \mathrm{RHO})^{0.454}\right]$

(9) Land-locked lobound model (Reckhow, 1979) -- P = LOADP/ $(16+Q S)$

(10) Land-locked hibound model (Reckhow, 1979) -- P = LOADP/ 13.2

where: $P=$ Predicted total phosphorus $\left(\mu_{8} / \mathrm{L}\right)$

DEVP $=$ percentage of drainage area developed

LOGVOL = natural log of lake volume (acre-feet)

LOADP = annual load of phosphorus per unit

lake area $\left[\left(\mathrm{mg} / \mathrm{m}^{2}\right) / \mathrm{yr}\right]$

$z=$ mean lake depth $(m)$
RHO = annual runoff per unit lake volume (annual flushing rate, dimensionless) RHOLOG = natural $10 \mathrm{~g}$ of RHO QSLOG = natural 108 of $Q S$ $\mathrm{QS}=$ annual runoff per unit lake area $(\mathrm{m} / \mathrm{yr})$ $\exp =e^{a}=(2.71828 \ldots)^{a}$ 
Table 4.--Results of phosphorus-prediction models compared to the median phosphorus concentration for 1982-83

Total phosphorus concentration in micrograms per liter

$\begin{array}{ll}\text { Median } & \text { Predicted by model (number) } \\ \text { concentration } & \end{array}$

Lake

$1982-83$

(1)

(2)

(3)

(4)

(5)

(6)

(7)

(8)

(9)

(10)

\begin{tabular}{|c|c|c|c|c|c|c|c|c|c|c|c|}
\hline Fish & 20 & 160 & 140 & 160 & 19 & 12 & 45 & 26 & 69 & 10 & 12 \\
\hline Holland & 30 & 97 & 98 & 190 & 14 & 19 & 43 & 29 & 74 & 15 & 19 \\
\hline Jens en & 30 & 76 & 110 & 99 & 30 & 11 & 64 & 37 & 66 & 8 & 11 \\
\hline Slater's Acres & 30 & 160 & 150 & 220 & 85 & 64 & 260 & 180 & 220 & 51 & 73 \\
\hline McCarthy & 40 & 120 & 150 & 160 & 78 & 40 & 200 & 140 & 160 & 32 & 45 \\
\hline Donaldson's & 50 & 210 & 200 & 420 & 71 & 340 & 570 & 420 & 470 & 290 & 590 \\
\hline Lemay & 50 & 190 & 260 & 310 & 94 & 59 & 270 & 170 & 250 & 47 & 63 \\
\hline Shanahan & 50 & 110 & 130 & 120 & 44 & 17 & 100 & 63 & 94 & 14 & 18 \\
\hline Blackhawk & 60 & 130 & 180 & 180 & 53 & 25 & 130 & 79 & 130 & 20 & 26 \\
\hline Burview & 60 & 150 & 110 & 240 & 86 & 97 & 310 & 220 & 260 & 79 & 120 \\
\hline Wilderness & 70 & 190 & 300 & 260 & 110 & 42 & 250 & 160 & 220 & 33 & 44 \\
\hline Lakeside & 80 & 160 & 230 & 220 & 61 & 29 & 150 & 90 & 150 & 23 & 30 \\
\hline Thomas & 130 & 110 & 140 & 120 & 46 & 15 & 98 & 59 & 91 & 12 & 15 \\
\hline Cedar & 150 & 220 & 300 & 320 & 170 & 460 & 710 & 510 & 590 & 420 & 1100 \\
\hline Langhoven & 180 & 200 & 240 & 230 & 370 & 170 & 550 & 470 & 470 & 140 & 220 \\
\hline
\end{tabular}


retention basins, (6) magnitude and impacts of nutrient flushing into and out of lakes, (7) impact of flushing or loading at various seasons, and (8) rates of internal nutrient loading. Another factor that needs to be considered in developing new models for the Eagan lakes, is that phosphorus probably would be introduced primarily from the direct drainage area because particulate phosphorus would settle-out in ponding areas, whereas, flushing can result from runoff from both the direct and indirect drainage areas and decrease the average residence time of water in the lake.

\section{SUMMARY AND CONCLUSIONS}

The 16 lakes in Eagan that were sampled for this study generally are similar but specifically are unique. None of the lakes have natural inlets or outlets, and they probably are connected hydraulically to ground water in the surficial glacial drift. Most of the lakes have been incorporated into the city's storm-sewer system and have artificial inlets and outlets. The average of measurements made near the surface of the lakes during this study showed that specific conductance ranged from 102 to $462 \mu \mathrm{S} / \mathrm{cm}$ and chloride concentrations ranged from less than $5 \mathrm{mg} / \mathrm{L}$ to more than $30 \mathrm{mg} / \mathrm{L}$. Average total phosphorus concentrations and transparency also ranged widely from 0.02 to $0.18 \mathrm{mg} / \mathrm{L}$ and from 0.22 to 2.7 meters, respectively, during the sampling.

Many changes in the morphology and quality of the lakes occurred since the previous study was completed. Changes in lake depth may be attributed to either or a combination of (1) installation of the storm-sewer system that increased runoff to the lakes, (2) above-normal precipitation that increased runoff to the lakes during the study period, (3) elevated ground-water levels that caused elevated lake levels, or (4) partial filling of the lake by sediment transported with the runoff. Statistically significant increases in chloride and specific conductance in many of the lakes indicate that substantial amounts of urban runoff are entering the lakes.

Detrimental effects anticipated as a result of urban runoff to the lakes, including contamination by chloride, oil and grease, and pesticides, seem to be offset by the advantage that the lakes occasionally are flushed by runoff that contains lower concentrations of total phosphorus. Several of the lakes that receive urban runoff had improved transparency and reduced concentrations of total phosphorus since the previous study, changes which occasionally were statistically significant. In some lakes, however, phosphorus was reduced but transparency was less, indicating that some of the data are inconclusive or that other mechanisms are affecting lake productivity.

Urban runoff to a lake in a community adjacent to Eagan has been shown to contain elevated concentrations of phytotoxic metals, but not at harmful levels. If concentrations of these metals were sufficient, phytoplankton would be killed and would carry cellular phosphorus to the sediment on the lake bottom. This would reduce concentrations of phosphorus and chlorophyll and improve transparency, resulting in the measured improvement in trophic status. 
The average trophic status of the Eagan lakes based on summer values of total phosphorus improved more than 8 units since the previous study, but a variety of changes were observed. Trophic status improved substantially in seven of the lakes and the greatest improvements, more than 30 index units, were measured in McCarthy Lake and Slater's Acres Pond. Four lakes had a higher trophic-state index, indicating the trophic status had declined; the greatest increase, 14 units, occurred in Holland Lake.

Phosphorus-1oading lake-quality models developed during the previous study were tested with the recently acquired data and generally were found to be inadequate. The deep-lake model developed by Ayers and others (1980) was determined to be the most accurate, predicting in-lake phosphorus concentrations to within 5 percent in Fish Lake and 20 percent in 4 of the 14 shallow lakes. The accuracy of the models probably is limited because they do not consider ground-water flux, recycling and flushing of phosphorus, interactions between fish, zooplankton, and phytoplankton, the impact of rooted aquatic plants, and a multitude of other factors related to the effects of the stormsewer system on phosphorus concentration in the lakes.

Results from this study indicate that the Eagan lakes generally behave independently from one another, with a multitude of unquantified and variable influences affecting the water quality. Comparisons between past and present lake quality are difficult because average precipitation between the two periods changed substantially and because relatively few samples were available for statistical analysis.

Subsequent studies could be made to assess the long-term effect of runoff received by the lakes, but need to be designed with a different emphasis. A few key lakes studied over a longer period might explain many of the variations observed. Gaged inflow and outflow with intensive storm-runoff sampling would better quantify loading and flushing to and from the lakes. Ground water in the vicinity of the lakes could be monitored to determine the degree of interaction between ground water and the lakes and to determine the effect of urban runoff on the quality of the ground water. 
Ayers, M. A., Payne, G. A., and Have, M. R., 1980, Effects of urbanization on the water quality of lakes in Eagan, Minnesota: U.S. Geological Survey Water-Resources Investigations 80-71, $42 \mathrm{p}$.

Ayers, M. A., Brown, R. G., and Oberts, G. L., 1985, Runoff and chemical loading in small watersheds in the Twin Cities metropolitan area, Minnesota: U.S. Geological Survey Water-Resources Investigations 85-4122, $35 \mathrm{p}$.

Bonestroo, 0. G., Rosene, R. W., Anderlik, J. C., and Associates, Incorporated, 1978, Comprehensive storm-sewer plan, Eagan, Minnesota: unpublished consulting report, $43 \mathrm{p}$.

1984, Comprehensive storm-sewer plan, Eagan, Minnesota: unpublished consulting report, $65 \mathrm{p}$.

Brown, R. G., 1985, Hydrologic factors affecting lake-level fluctuations in Big Marine Lake, Washington County, Minnesota: U.S. Geological Survey WaterResources Investigations Report 85-4176, 23 p.

Carlson, R. E., 1977, A trophic state index for lakes: Limnology and Oceanography, v. 22, no. 2, p. 361-369.

Chapra, S. C., and Tarapchak, S. J., 1976, A chlorophyll a model and its relationship to phosphorus loading plots for lakes: Water Resources Research, v. 12 , no. 6, p. 1260-1264.

Dillon, P. J., and Rigler, F. H., 1974, The phosphorus-chlorophyl1 relationship in lakes: Limnology and Oceanography, v. 19, p. 767-773.

Gough, L. P., Shacklette, H. T., and Case, A. A., 1979, Element concentrations toxic to plants, animals, and man: U.S. Geological Survey Bulletin 1466 $80 \mathrm{p}$.

Greeson, P. E., Ehlke, T. A., Irwin, G. A., Lium, B. W., and Slack, K. V., 1979a, Methods for the collection and analysis of aquatic biological and microbiological samples: U.S. Geological Survey Techniques of WaterResources Investigations, book 5, chap. A4, 332 p.

Greeson, P. E., Ehlke, T. A., Lium, B. W., Shoaf, W. T., Radtke, D. B., and Sohn, I. G., 1979b, A supplement to--methods for collection and analysis of aquatic biological and microbiological samples (U.S. Geological Survey Techniques of Water-Resources Investigations, book 5, chap. A4): U.S. Geological Survey Open-File Report 79-1279, 92 p.

Have, M. R., 1975, Some limnological aspects of 20 selected lakes in Eagan and Apple Valley, Minnesota: U.S. Geological Survey Open-File Report 75-528, $56 \mathrm{p}$. 
Have, M. R., Payne, G. A., and Ayers, M. A., 1981, Water quality of Alimagnet, Farquar, and Long lakes in Apple Valley, Minnesota: U.S. Geological Survey Water-Resources Investigations Report 81-40, $38 \mathrm{p}$.

Jones, J. R., and Bachmann, R. W., 1976, Prediction of phosphorus and chlorophyll levels in lakes: Journal of Water Pollution Control Federation, v. 48, no. 9, p. 2176-2182. Minnesota Pollution Control Agency, 1978, Rules, regulations, classifications, and water standards: St. Paul, Minnesota, Office of State Registrar, Department of Administration.

National Oceanic and Atmospheric Administration, 1983, Climatological data, annual summary: Minnesota, 1982, v. 88, no. 13, 32 p.

1984, Climatological data, annual summary: Minnesota, 1983, v. 89, no. $13,32 \mathrm{p}$.

Reckhow, K. H., 1979, Quantitative techniques for the assessment of lake quality: Washington, D. C., U.S. Environmental Protection Agency, 146 p.

Skougstad, M. W., Fishman, M. J., Friedman, L. C., Erdmann, D. E., and Duncan, S. S., 1979, Methods for analysis of inorganic substances in water and fluvial sediments: U.S. Geological Survey Techniques of Water-Resources Investigations, Book 5, Chapter A1, $626 \mathrm{p}$.

Snedecor, G. W., and Cochran, W. G., 1967, Statistical methods, 6th edition: Iowa State University Press, Ames, Iowa, 593 p.

U.S. Department of Commerce, 1982, Number of inhabitants (in) Minnesota, chap. A of 1980 Census of population: Characteristics of the population, PC $80-1-\mathrm{A} 25,67 \mathrm{p}$.

U.S. Geological Survey, 1975, Water resources data from Minnesota, 1973-74-part 2. Water-quality records: U.S. Geological Survey Water-Data reports (published annually).

1976-77, Water resources data for Minnesota, 1975-76: U.S. Geologica1 Survey Water-Data Reports MN-75-1 and MN-76-1 (published annually).

1978-79, 1983-84, Water resources data for Minnesota, water years 1977-78, 1982-83, volume 2: U.S. Geological Survey Water-Data Reports MN-77-1 to MN78-1 and $\mathrm{MN}-82-2$ to $\mathrm{MN}-83-2$ (published annually).

Walker, W. W., Jr., 1977, Some analytical methods applied to lake water-quality problems: unpublished Ph.D. dissertation, Harvard University.

Wetzel, R. G., 1975, Limnology: W. B. Saunders Company, Philadelphia, Penn., $743 \mathrm{p}$. 